NBER WORKING PAPER SERIES

\title{
HOW CENTRAL BANKERS SEE IT: THE FIRST DECADE OF ECB POLICY AND BEYOND
}

\author{
Stephen G. Cecchetti \\ Kermit L. Schoenholtz \\ Working Paper 14489 \\ http://www.nber.org/papers/w14489
NATIONAL BUREAU OF ECONOMIC RESEARCH
1050 Massachusetts Avenue
Cambridge, MA 02138
November 2008

The authors are Economic Adviser and Head of the Monetary and Economic Department, Bank for International Settlements, Research Associate, National Bureau of Economic Research and Research Fellow, Centre for Economic Policy Research; and Senior Advisor and Managing Director of Citi Economic and Market Analysis. This paper was prepared for the NBER conference "Europe and the Euro," 17-18 October 2008, Milan, Italy. It is traditional to use the introductory footnote to thank colleagues who contributed comments and advice. In this case, there were dozens of people without whom we could not have written this paper. First, 17 senior officials sat for interviews that their staffs helped organize; second, Citigroup facilitated interview transcription; third, several economists helped with data and filled in parts of the history (notably, Jose Luis Alzola); and finally, the editors of this volume spurred us to write this paper. To all of them we extend our heartfelt thanks. We also would like to thank Alberto Alesina, Vitor Gaspar, and Francesco Giavazzi for comments on an earlier draft; and Malcolm Spittler of Citigroup for his excellent research assistance. The views expressed herein are those of the author(s) and do not necessarily reflect the views of the National Bureau of Economic Research.

NBER working papers are circulated for discussion and comment purposes. They have not been peerreviewed or been subject to the review by the NBER Board of Directors that accompanies official NBER publications.

(C) 2008 by Stephen G. Cecchetti and Kermit L. Schoenholtz. All rights reserved. Short sections of text, not to exceed two paragraphs, may be quoted without explicit permission provided that full credit, including $\odot$ notice, is given to the source. 
How Central Bankers See It: The First Decade of ECB Policy and Beyond

Stephen G. Cecchetti and Kermit L. Schoenholtz

NBER Working Paper No. 14489

November 2008

JEL No. E42,E58

\begin{abstract}
$\underline{\text { ABSTRACT }}$
In this history of the first decade of ECB policy, we also discuss key challenges for the next decade. Beyond the ECB's track record and an array of published critiques, our analysis relies on unique source material: extensive interviews with current and former ECB leaders and with other policymakers and scholars who viewed the evolution of the ECB from privileged vantage points. We share the assessment of our interviewees that the ECB has enjoyed many more successes than disappointments. These successes reflect both the ECB's design and implementation. Looking forward, we highlight the unique challenges posed by enlargement and, especially, by the euro area's complex arrangements for guarding financial stability. In the latter case, the key issues are coordination in a crisis and harmonization of procedures. As several interviewees suggested, in the absence of a new organizational structure for securing financial stability, the current one will need to function as if it were a single entity.
\end{abstract}

Note to readers: The final version of this paper was completed in June 2008.

Stephen G. Cecchetti

Monetary and Economic Department

Bank for International Settlements

Centralbahnplatz 2

4002 Basel

Switzerland

and NBER

stephen.cecchetti@bis.org

Kermit L. Schoenholtz

Economic and Market Analysis

Citigroup

388 Greenwich Street

28th Floor

New York, New York 10013

kim.schoenholtz@citi.com 


\section{Introduction}

Otmar Issing: "There was a clear view from a number of outside observers that we would fail and that it would be a disaster in any respect."

As late as 1997, less than a year before the European Central Bank (ECB) was scheduled to come into existence, there was widespread skepticism about whether European Monetary Union (EMU) would begin on schedule as a broad union and, in some quarters, whether it would happen at all. Yet, here we are a full decade after the advent of EMU and today there are 15 countries where the euro is legal tender. The 21 members of the Governing Council of the ECB make monetary policy for a region of 320 million people with a GDP of roughly $€ 9$ trillion. And it is hard to find major fault with what they have done over the past decade.

In this paper, we begin with a brief history of the challenges that faced the people who forged the policies of the ECB in its first decade. What tests did these central bank pioneers face as the European Monetary Institute was transformed into the ECB on 1 June 1998? With hindsight, it is fair to say that the preparations were a success in nearly every way. The ECB was able to conduct monetary policy operations immediately without a major misstep. The original Governing Council’s interest rate decisions were sound, overcoming a lack of data and models that would have panicked most people. While communication at the start may not have been as smooth as some people wished, it improved over time. Looking back, nearly every possible contingency that the ECB actually faced was anticipated and successfully addressed, reflecting careful preparation and unusual foresight.

Our task does not stop at recounting the past. Looking forward, we go on to ask what the likely challenges are for the next decade. The ECB is an evolving institution that is changing in unique ways. The euro area continues to expand. Enlargement could bring 10 additional members into the monetary union over time - and more if the European Union itself grows. Each of these countries has its own language, cultural traditions, and social norms. Adding them to the Eurosystem affects decision making and communication, as well as policy itself. 
Beyond increasing its size, the ECB faces challenges in retaining public support for its own policies and in promoting the structural reforms needed to increase the flexibility of member economies. Regional economic divergences within a country may create problems, but they are unlikely to be as severe as the political difficulties that the ECB is likely to face should the economies of the various countries in the euro area experience dramatically different economic fortunes for extended periods. Furthermore, as we look forward, prosperity in Europe does not depend on monetary policy alone. The decisions by member governments have an important impact on what the ECB can and cannot achieve.

Finally, there is the question of financial stability. Here, the ECB position as a pan-euro-area financial institution is unique. While the Governing Council has clear control over the combined balance sheet of the central banks in the Eurosystem (those of the National Central Banks plus that of the ECB itself), it does not have regulatory or supervisory authority. And, unlike the United Kingdom, where regulation and supervision resides in a single institution, financial oversight in the euro area is at the national level and each country is different.

In drafting this history, we have benefited from many studies that analyzed ECB policy, from its rate-setting patterns to its effectiveness in securing price and economic stability to its communication efforts. The ECB itself has been an excellent source, reflecting its admirable penchant for self-assessment. ${ }^{1}$ But there is no shortage of outside reviews and critiques. ${ }^{2}$ Furthermore, we now have nearly a decade of data with which to characterize the economic outcomes of ECB policy.

However, our unique advantage arises from a series of 17 extended interviews conducted between June 2007 and February 2008 with a range of current and former ECB policymakers, and with other policymakers and scholars who viewed the evolution of the ECB from privileged vantage points outside the institution. The questionnaire that we employed as a basis for the

\footnotetext{
${ }^{1}$ The Monetary Policy of the ECB, first published in 2001 and revised in 2004, as well as Issing et al. (2001) are early examples of comprehensive explanations and assessments.

${ }^{2}$ A list would start with the Monitoring the European Central Bank series published by the Centre for Economic Policy Research in London, and include analysis from the Observatorio del Banco Central Europeo in Madrid as well as the Centre for European Policy Studies in Brussels.
} 
interviews forms Appendix A of this paper. Appendix B reports the prominent themes in response to these questions. Abbreviated biographies of the interviewees are in Appendix C.

The ground rules for our interviews were straightforward: We asked each interviewee to review and correct an edited transcript of the interview, adding or deleting anything they wished. While we have used their responses to inform our judgment and understanding, all direct quotes in either the main text or the footnotes have been approved by the interviewees. We are very grateful for their generous support, especially considering that our interviews were conducted during the financial crisis that began in August 2007.

The remainder of this paper proceeds as follows. This introduction is followed by a brief discussion of the initial conditions in 1998 and the challenges that participants expected as monetary union was getting under way. In Section III, we move to a more detailed discussion of the construction of the ECB's operational framework, including the creation of the euro-area money market as well as the initial implementation of the policy and communication strategies. We then proceed to an evaluation of ECB policy performance in the first decade of monetary union in Section IV. We provide a brief discussion of the euro-area inflation experience, as well as the stresses and strains created by various aspects of the policy strategy. Section V looks to the future. Here, we report on the key challenges that our interviewees foresee over the second decade of EMU. Enlargement and financial stability are the issues that are clearly on people's minds, so that is where we focus most of our attention. Section VI concludes.

While we base nearly everything that we write on the series of interviews we conducted, the narrative that follows (including any errors or faulty judgments) is our own. We include extensive quotes in the form of footnotes to provide a sense of why we have drawn the conclusions that we have. 


\section{Initial Conditions}

Jean-Claude Trichet: "The main challenge we saw was to transfer to the new currency what had been promised: namely, that it would be as confidence inspiring, as credible, and as good a store of value as the previous national currencies had been."

The European Central Bank (ECB) came into existence on June 1, 1998 - replacing its predecessor, the European Monetary Institute (EMI). At the start of 1999, the ECB took over monetary control in the initial 11 countries of the euro area.

The ECB was a new and unprecedented institution without a track record, but it was not born in a vacuum. The Treaty of Maastricht provided for its independence from governments and established a hierarchical mandate for ECB policy with price stability as the top priority. ${ }^{3}$ Because any alteration of the Treaty requires unanimous support of the member states of the European Union, this mandate remains widely perceived as immutable. While the ECB began with only a few hundred employees, it drafted a significant portion of its staff from national central banks (NCBs) which, together with the ECB, form the Eurosystem.

Nevertheless, the policy tests facing the ECB at its inception were numerous and daunting. Section I.a. of Appendix B identifies the most prominent concerns that our interviewees perceived when the ECB began. From this list, it is evident that the ECB faced an extraordinary challenge as it sought to inherit from the start the credibility of its most successful predecessor central banks. ${ }^{4}$ There also were great risks, as there would be no honeymoon or grace period. Any significant rise of inflation expectations or of inflation risk premia in the run-up to EMU might have branded policy a failure even before the ECB began to exercise monetary control.

By day one, the new central bank needed to promote the development of a euro-area-wide money market in which it could operate. The Eurosystem needed to determine which matters would be centralized within the ECB, and which would be delegated to the NCBs for execution or

\footnotetext{
${ }^{3}$ The Treaty allows the region's finance ministers to negotiate an international agreement (such as a fixed exchange rate regime) that could theoretically override ECB monetary independence. So far, however, there has been no such proposal, let alone indications of consensus among finance ministers to alter the floating-rate regime.

${ }^{4}$ Axel Weber: "The biggest challenge for the newly-founded Eurosystem - operating without a track record - was to gain credibility in financial markets and among the citizens of Europe.”
} 
oversight. There was concern whether the powerful NCB Governors - and their large staffs would overwhelm the ECB, and potentially undermine the euro-area focus of the new central bank. ${ }^{5}$ While the EMI had narrowed the options for the policy strategy, the ECB had only seven months in 1998 to consider specific alternatives (principally inflation or monetary targeting), to specify the strategy in detail (including the operational methodology), and to prepare the apparatus for making decisions and communicating. In doing so, it lacked the timely data and reliable models of the euro area that modern central bankers rely on in making policy rate decisions. Moreover, the structural changes induced by the creation of the euro - which favored a rapidly integrating financial market and economy - meant fundamental uncertainty about the monetary transmission mechanism. In a virtually unique manner, at the start the ECB had to manage a currency that did not exist in notes or coin.

And, the ECB was to begin operations in an environment of overt skepticism. ${ }^{6}$ Some observers anticipated currency disturbances reminiscent of the ERM crises even after the start of EMU (see, for example, Garber (1999)). ${ }^{7}$ Prior to EMU, it was common among prominent economists to conclude that the euro area's lack of labor mobility and of a mechanism for fiscal burdensharing made it a suboptimal currency area that would be prone to country-level divergences in activity, employment and fiscal balances (see Feldstein (1997) or Obstfeld (1998)).

Against this background, the broad membership of EMU - which included several formerly high-inflation countries - raised doubts about credibility: Would the euro-area yield curve be an amalgam of EMU member yield curves, or would it mimic those with the most favorable inflation track records (such as Germany, Benelux and France)? The former outcome might even have prompted speculation about secession from EMU, however difficult. Similarly, would cross-country yield spreads be so wide as to cast doubt on EMU's sustainability?

Finally, it was unclear at the outset to what extent monetary union would promote European political union, or even whether fiscal and supply-side reforms could keep pace with monetary and financial integration. EMU's most extreme critics viewed it as a political device to secure

\footnotetext{
${ }^{5}$ Six members of the ECB Executive Board would join 11 NCB Governors in the initial Governing Council. While exaggerated by the inclusion of NCB operational personnel, the NCB workforce was about 100 times larger than that of the ECB at the ECB's inception. At end-2007, ECB employment had trebled from its end-1998 level of 450, but was still only a fraction of NCB staff.

${ }^{6}$ Andrew Crockett: “A few years before the start most observers would not have believed you if you'd told them there would be 12 members, or at least 11 and soon 12, at the beginning of monetary union.”
} 
bureaucratic mastery over Western Europe, rather than as a means of promoting euro-area welfare. ${ }^{8}$

\section{An Operational Framework}

Otmar Issing: "What really shocked me [when I arrived] was the lack of any reasonable information (data, etc). We were preparing monetary policy for totally uncharted waters."

Alexandre Lamfalussy: "I feared that they would have technical problems of all kinds. Ultimately, I was wrong. The implementation went extraordinarily smoothly."

Vitor Gaspar: “An explicit strategy was clearly necessary to ensure the internal cohesion of the decision-making bodies of the ECB. It also was necessary to have a consistent framework which would enable the bank to communicate to a very diverse set of constituencies.”

In light of these initial conditions, how would the ECB secure the goal of price stability and the subsidiary goals established by the Treaty?

\section{$\underline{\text { A Single Money Market }}$}

No ECB policy using interest rates as a tool could be implemented effectively without the existence of a deep, efficient euro-area money market. Such a market did not exist before EMU. From a technical perspective, the Eurosystem introduced a real-time gross settlement system, TARGET, as the foundation for a single market for overnight liquidity at the start of the ECB. The system had to be fully functional by January 4, 1999 when the ECB conducted its first openmarket operation. ${ }^{9}$ Interviewees who were involved in these preparations recalled concern about the lack of time for testing and worries that any operational failure would significantly damage the reputation of the ECB and the single currency even before it got going. There was at least one brief occasion in the Spring of 1999 when money markets seemed slow to react to policy developments, but TARGET has been viewed as an extraordinary achievement, bringing about a

\footnotetext{
${ }^{7}$ Vitor Gaspar: "People worried about the possibility of turbulence in the foreign exchange markets.”

${ }^{8}$ See, for example, Connolly (1995). With regard to the ECB, Connolly writes: "But if the ECB is ever created, it will certainly not act in a disinterested way in the interest of the Community as a whole, simply because there is no such thing as the Community interest. Either it will act in French interests or it will not. If it does, then Germany will destroy it, putting an end to fifty years of a 'European Germany.' If it does not, then it might well destroy France.” (page 391)

${ }^{9}$ Christian Noyer: "The greatest concern was to be sure to start operations effectively on the $4^{\text {th }}$ of January 1999 . If we wanted to have a single money market functioning in euros, we needed absolutely to have the TARGET system working to enable banks to exchange liquidity and the central bank to intervene. We needed the system working from the start to enable us to provide liquidity to the market."
} 
near-instant integration of the national markets for overnight liquidity. Further evolution of TARGET over the years (including the November 2007 introduction of TARGET II) built effectively on this success.

In contrast, several interviewees viewed the public reaction to the 2002 introduction of euro notes and coin as the ECB's greatest self-made disappointment in its first decade. From a technical perspective, this enormous logistical process went more quickly and smoothly than many had expected. Most of the legacy currency was replaced within a matter of weeks, rather than months, and there were no notable disruptions of retail activity. Official estimates indicate that the changeover boosted the price level on average by $0.12 \%-0.29 \%$ (Eurostat (2003)). ${ }^{10}$ However, as the ECB subsequently observed, this modest one-off price adjustment prompted an unanticipated (albeit temporary) rise of inflation expectations in some countries that may have contributed to doubts about EMU in the public mind. (Various explanations of this phenomenon may be found in the essays collected in Del Giovanni and Sabbatini (2008) as well as in Dzuida and Mastrobuoni (2007)). Some policymakers still wonder whether a more aggressive communication effort would have anticipated and blunted these doubts. ${ }^{11}$

\section{Objectives and Strategy}

Prior to the start of operations, the ECB stated a quantitative definition of price stability: inflation of less than 2\% as measured by the Harmonized Index of Consumer Prices (HICP). Some outside observers criticized this goal as asymmetric (in contrast with the inflation level or bandwidth objectives commonly used by inflation-targeting central banks). Concerns about goal asymmetry appeared particularly acute amid the deflation scare earlier in this decade. In 2003, following a broad policy review, the ECB clarified its numerical objective, but did not alter it substantively it was restated as "less than, but close to 2\%". Since that time, the ECB's announced goal has not changed, and objections to its asymmetry have waned. In part, that may reflect the judgment of

\footnotetext{
${ }^{10}$ Popular claims that official measures understate the price impact of the changeover have not been supported by subsequent analysis (see Del Giovane and Sabbatini (2008)).

${ }^{11}$ According to Eurobarometer 58 (2003), 77\% of euro-area respondents judged that prices had been "rounded up" during the conversion to the euro. Ignazio Angeloni: "None of us thought at the beginning that a key problem would come from the introduction of the euro bank notes and coins (rather than from the 1999 introduction of the euro).... Specifically, I refer to the impact of the introduction of the euro on retail prices and to the effect on expected inflation and perceived inflation in particular."
} 
some observers that the actual target is roughly symmetric around $2 \%$ (see Galí et al., 2004). The ECB's response to the record 2008 overshoot of its target appears consistent with that view.

In October 1998, the ECB announced the "two-pillar" strategic framework that included a focus on monetary developments (Pillar I) and on all other factors affecting the economic and inflation outlook (Pillar II). The official policy review in 2003 left these two pillars in place, but described the approach in a more eclectic (and less mechanical) fashion that focused on the use of the monetary pillar as a "cross-checking" device in which monetary analysis utilizes a broad array of financial variables. Galí et al. (2004) characterized the 2003 shift as a de-emphasis of M3 growth that made clear that "money growth is not an alternative policy target."

There is a voluminous literature studying this unique framework, which would seem to be neither fish (inflation targeting) nor fowl (monetary targeting). Much of the analysis from outside the ECB has criticized the monetary pillar as superfluous in securing price stability under a flexible inflation-targeting framework; Svensson (2000) quipped that the first pillar was really just a brick in the second pillar. One early study argued that the negative correlation between monetary signals and policy rates in some periods confirms that the ECB "ignores the monetary pillar” (see Begg et al., 2002). A later analysis expressed doubt that policy decisions would have been any different had been there no "explicit role for money” (see Galí et al., 2004).

In contrast, ECB analysis has focused on establishing the importance of monetary developments for price stability over a horizon longer than that of most economic forecasts. ECB officials, such as Issing (2003), also have suggested that monetary developments can help policymakers anticipate threats to price stability from asset price bubbles. Nevertheless, ECB policymakers have been obliged to account for sustained overshoots of monetary aggregates beyond reference values that have not appeared linked to price developments. This pattern has tended to downgrade the perceived policy importance of such overshoots and has reinforced doubts about the monetary pillar on the part of many skeptics. It remains distinctly possible that the modest signal-to-noise ratio of monetary developments eventually could erode the credibility of a central bank that emphasizes its reliance on information from monetary analysis. 
However one may view the lingering debate about the two pillars, as Issing (2006) emphasizes, critics underestimate the historical utility of the hybrid strategy in securing for the ECB from its inception the credibility of its most effective predecessor, the Bundesbank. Failure to do so at the start could have been extremely costly, if not irretrievable. By its nature, the ECB must communicate to a more diverse public than virtually any central bank. Even in the distant future, the differences in languages, traditions, institutions, and legal systems across EMU members are unlikely to disappear. In Germany - which represented one third of EMU economic activity at the start - the association of low inflation with Bundesbank monetary targeting in the public mind probably warranted an ECB emphasis on euro-area monetary developments as a means to anchor inflation expectations. Achieving this desired continuity required a consistency of objectives and communication mechanisms suited to the unique historical circumstances. Looking forward, it remains to be seen whether the ECB's low-inflation reputation will spur it over time to simplify the policy strategy while keeping inflation expectations well-anchored. ${ }^{12}$

\section{Communications}

Otmar Issing: "Translation was, of course, linguistically always very good, but the same words and phrases may seem different against the background of different historical experiences. For example, one colleague once said to me, 'Otmar, we have a paragraph containing three times a reference to price stability. I think this is too much for this argument. In my country, if you say three times why you seek price stability, it weakens your argument.' And my argument was, if in Germany it's only two times, they say, 'Oh, is the ECB less stability oriented than the Bundesbank?'”

In the course of linking its communication strategy with its objectives and instruments, the ECB developed innovative mechanisms for communication to compensate for constraints that differentiate it from other large central banks. Like most modern central banks, the ECB views transparency both as a goal in itself - necessary for accountability in a democratic society - and as a means to make its policies more effective. ${ }^{13}$ It is now a commonplace that central bank policy is transmitted to the economy through forward-looking financial markets, so that clear

\footnotetext{
${ }^{12}$ For example, Papademos (2006) describes how the two pillars eventually could merge into one.

${ }^{13}$ Lucas Papademos: "What matters for the effectiveness of communication is to explain as clearly as possible the decisions taken and the policy being implemented in relation to the central bank's objective and strategy. It is essential to explain how the monetary policy stance contributes to the achievement of the objective. The more transparent and convincing a central bank is about the consistency of its actions with its objective and strategy, the greater the effectiveness of its policy." See also European Central Bank (January, 2006).
} 
objectives, a systematic approach to analysis and decisions, and timely public statements are indispensable.

Yet, the ECB has also been keen to shield individual members of the Governing Council from pressures to pursue national, rather than euro-area, policy goals. The concern, which appeared particularly acute at the start of EMU but remains notable today, is that domestic politics could make Council members less inclined to support policies that would be in the best interests of the euro area, but not necessarily optimal for their home countries. For this reason, the ECB eschews the publication of minutes that would detail Council members' statements or votes. ${ }^{14}$ The ECB's alternative - the immediate post-meeting press conference held by its President - narrows the information loss due to the lack of detailed minutes, while accelerating the diffusion of the consensus judgment. ${ }^{15}$

As with other major central banks, ECB communications is a work in progress characterized by a trend toward greater transparency. Some interviewees noted that, in the early years, failure to synchronize public statements by Governing Council members occasionally contributed to confusion. ${ }^{16}$ Jansen and de Haan (2004) show that NCB Presidents "made at least as many statements” in the early years as the Executive Board, but also indicate that the frequency of contradictions in statements about interest rates declined over time. The observed decline in the implied volatility of options on short-term futures also suggests that ECB communication with markets has become more effective (see ECB (2006)).

Other changes also reflect the maturing of the institution (including its data set and models): For example, the ECB began to publish its semi-annual staff economic forecasts in December 2000, subjecting internal views to wide external scrutiny. More broadly, the ECB has developed an active dialogue with the public regarding its practices and their evolution. ECB seminars, conferences and official participation in outside programs like the ECB Watchers’ Conference promote an exchange of ideas with academicians, market practitioners, and others. In the official

\footnotetext{
${ }^{14}$ Fabrizio Saccomanni: "[P]ublication of minutes would be taken in Europe as an excuse to speculate about national preferences regarding monetary policy. We have to be careful not to create unnecessary problems of sensitivity at the national level."

${ }^{15}$ Sirkka Hämäläinen: "From the very beginning, I have seen the press conference as the best way to communicate."
} 
sector, the ECB also pursues active communication through frequent parliamentary testimony and routine contact with the Eurogroup, ECOFIN and the European Commission. ${ }^{17}$

At least one recent study by Eijffinger, Geraats, and van der Cruijsen (2006) compares the level of ECB transparency favorably with that of other central banks. ${ }^{18}$ Our own judgment, which coincides with the consensus of interviewees, is that there is no single "best practice" with regard to transparency and communication. ${ }^{19}$ Communication is about language and gesture, both of which depend on tradition and history. Effective signaling under constraints requires a thorough understanding of how the signals will be received (which may differ across languages and cultures) and also about which signals could distort the incentives of policymakers and, thereby, undermine the benefits of transparency. In the words of John Taylor, "More talk does not mean more transparency.” At the same time, the ECB's tendency to describe its decisions as unanimous may understate the nature and vigor of important Governing Council debates, thereby diminishing the ability of observers to make an informed judgment about policy and sustaining skepticism about ECB communications more generally.

A key question that arises frequently today is whether central banks should announce an expected path of future policy rates. Ultimately, to maximize the effectiveness of monetary policy, the signals and means of signaling need to be consistent with a central bank's objectives and strategy. Such announcements systematically reinforce policy goals through rapid market adjustments. At the same time, excessive concreteness that surpasses the ability of policymakers to reliably anticipate future developments can be counterproductive. For these reasons, it is far from clear that publication of an expected future policy rate would be optimal for all central

\footnotetext{
${ }^{16}$ Sirkka Hämäläinen: “Communication and public statements of the members of the Governing Council (the Board members included) were not initially always fully synchronized and thus monetary policy messages sent to markets were somewhat confusing."

${ }^{17}$ Jean-Claude Trichet: "I have to explain regularly and tirelessly all over Europe that I am as frequently in Brussels with the European Parliament as Ben Bernanke and Alan Greenspan appears and appeared before Congress, perhaps even a little bit more frequently.... I invited twice a month the President of the college of Ministers of Finance (the Eurogroup) to attend the Governing Council meeting of the ECB.... I am, myself, invited every month to attend the meetings of the Ministers of the euro area. Three times a month, there is physical contact between the ECB's Governing Council and the executive branches and the Commission." ${ }^{18}$ However, public perceptions of ECB transparency may be less favorable: See Eijffinger and van der Cruijsen (2007).

${ }^{19}$ Philipp Hildebrand: "The notion that you could somehow hold up the Norwegian model or the Swedish model or the Swiss model as the right model for the ECB strikes me as slightly naïve.”
} 
banks (which have different objectives and constraints) or on all occasions for a particular central bank (which may face periods of heightened uncertainty). ${ }^{20}$

The same judgment could be applied to the use of "code words" to signal policy intentions. Codes are imperfect signals at best, and typically relate only to near-term policy prospects, which may be of least importance in the formulation of critical long-run market expectations. Rather, these expectations depend sensitively on the transparency and reliability of the central bank's reaction function, along with an understanding of the evolution of prices and the economy.

The role of signaling in the monetary transmission mechanism highlights how important it is for central banks to understand markets and their policy responses. Central bankers know that any slavish response to market expectations runs the risk of creating price-level or inflation indeterminacy. At the same time, equilibrium in markets requires that the expectations of market participants and central bank decision makers coincide. Consequently, to make their policies most effective, central banks need to understand how markets behave and how to affect expectations without diminishing market incentives for price discovery.

In the case of the ECB, we suspect that the lack of direct financial market experience on the part of most Governing Council members may have complicated this task. The first-decade record is filled with outside complaints about ECB communication with financial markets. Much of this criticism underestimates the political constraints under which a multinational organization such as the ECB functions and the challenge of communicating with so many diverse constituencies. Nevertheless, a greater presence of senior ECB leaders with financial market (rather than central bank) experience might have sped the evolution of the central bank's communications.

\section{Data, Models and Policy Analysis}

Over the first decade of EMU, the ECB has made enormous strides in developing data for and models of the euro-area economy, as well as advancing the frontiers of policy analysis. In the early years of EMU, the lack of consistent, timely euro-area-wide data added sharply to policy

\footnotetext{
${ }^{20}$ For a view calling on the ECB to announce an explicit rate path, see Geraats et al. (2008). For a counterargument from a
} 
uncertainty about the current state of the economy. Even near the end of 2000, for example, published euro-area output gap estimates of official institutions differed by nearly one percentage point, with the OECD figure standing at $-0.3 \%$ while the European Commission published an estimate of $-1.2 \%$. Moreover, recent readings show very large revisions to these "real-time" estimates - the current OECD measure of the euro-area output gap in 2000 is $+1.2 \%$, while the Commission's is $+1.9 \% .{ }^{21}$ The structural changes induced by EMU added to uncertainty, while the lack of models for the economy as a whole sharply limited the ability of policymakers to be forward-looking.

Perhaps as compensation, the decision-making process at the ECB allocated until recently a significant role to the Chief Economist in setting the stage for policy rate decisions. The likely effect was to enhance attention to the limited supply of timely aggregate data relative to the abundant supply of anecdotes in policy making, helping to narrow the grounds for policy debate. As a result, the "proposal power" inside the Governing Council may have been of greatest importance in the early years of EMU, precisely when the shortage of data and forecast models was most acute.

Today, there are still important gaps in the availability of timely euro-area data, although progress depends largely on advances outside the ECB. ${ }^{22}$ At the same time, the ECB has developed a forecasting apparatus that is at the state-of-the-art in the central banking world and as previously mentioned - routinely publishes its staff projections. In addition, the broad research program of the ECB has reached a status that puts it at the frontier of applied policy analysis alongside the best research efforts of other leading central banks and academic institutions.

\footnotetext{
member of the Governing Council, see Weber (2007).

${ }^{21}$ For comparison, the average of the output gaps in the year 2000 reported in the IMF World Economic Outlook of October 2000 (2007) for France, Germany and Italy was $-1.2 \%(+1.4 \%)$.

${ }^{22}$ For example, employment data are available in the United States within days of each reporting month, but only 75 days after the end of a reporting quarter in the euro area. Similarly, GDP data with breakdowns are available in the euro area at $t+65$ days, compared to t+31 days in the United States. And, in some euro-area countries, HICP flash estimates only recently became available. It is up to the national statistical agencies and Eurostat to change this, not the ECB. For a discussion of plans for improvement, see the report of the Economic and Financial Committee (2007) that was endorsed by the ECOFIN Council.
} 


\section{Eurosystem - A Constitutional Pact}

The Maastricht Treaty's map for the governance of the ECB and the Eurosystem is a complex one. How can the region’s central bankers actually make decisions and divide labor? From the point of view of monetary policy, a key question was whether policy determination would be truly euro-area oriented, or if it would reflect some ambiguous compromise arising from the pursuit of national interests? With fifteen NCB governors and six Executive Board members serving on the initial Governing Council, it is natural to wonder whether community interests might have been overwhelmed by national ones. At least one study examined (and rejected) the hypothesis that median voting of Council members sensitive to their domestic inflation conditions accounted for policy patterns in the ECB's early years (see Alesina et al., 2001).

Our interviews revealed unanimity among ECB insiders that country-specific factors were irrelevant in the policy rate-setting process even at the start of EMU. Having feared a greater role for national interests, some interviewees reported reacting with surprise and satisfaction at that time. ${ }^{23}$ Others suggested that the long process of preparing for EMU - including joint preparatory work at the EMI - had fostered a broad consensus among euro-area central bankers about the objectives and implementation of monetary policy that underpinned the ECB’s behavior. ${ }^{24}$

Interviewees also indicated that operational matters resulted in less willingness to don a "euroarea hat.” For example, efforts to streamline the Eurosystem - which would affect the locus of some operations and employment - were more likely to inspire national concerns. Perhaps not surprisingly, in 2007 the Eurosystem had 15 local mints accredited for production of euro notes, compared to only two mints in the United States. ${ }^{25}$

\footnotetext{
${ }^{23}$ Hans Tietmeyer: "[The decision-making process] was smoother than I anticipated, because I thought that the different traditions and structures of the national central banks could play a diverging role, and that at least some governors could be tempted to feel themselves primarily as representatives of a national area. But especially at the governors' level, there was a relatively broad-based common feeling from the beginning."

${ }^{24}$ Sirkka Hämäläinen "To me, it was quite clear that after those many years of working together it was natural to expect it to be very smooth.”

${ }^{25}$ For a discussion of euro note printing, see European Central Bank (October, 2007). It is worth mentioning that some Federal Reserve District Banks, despite their 84-year historical advantage over the Eurosystem, sustain branch operations that may no longer serve a clear economic purpose.
} 
Nevertheless, the Eurosystem has successfully addressed many critical questions requiring a judgment about how to divide labor between the ECB and the NCBs. Monetary policy operations are at the top of this list. Policy is set by the ECB and implemented by the NCBs with their local counterparties using contractual arrangements based on national laws. The ECB lays down the guidelines for open-market operations - such as the single list of collateral acceptable for repo and instructs the NCBs about the size of operations, but the NCBs conduct the operation. Unlike the U.S. Federal Reserve system, there is no single locus (such as New York) for open-market operations. Operations coordinated in this decentralized manner require sophisticated information and communication technology that did not exist in the early history of the Federal Reserve. $^{26}$

\section{The First Decade of Performance}

Axel Weber: "I think the success is the high degree to which price stability has been achieved.... Long-term inflation expectations have been stable and low and anchored at the level defined as price stability.”

Hans Tietmeyer: "From the beginning, the ECB was seen inside and outside the euro area as independent and credible."

Fabrizio Saccomanni: “The euro is now considered to be an important currency with a global role."

Timothy Geithner: “[S]ince the ECB has been setting monetary policy, it has not produced a sustained period of subpar growth; the euro area has not experienced greater volatility of economic growth; and there has certainly not been any erosion of inflation performance. These may not be the only measures of central bank credibility, but they suggest that the ECB is performing well.”

A review of the euro-area outcomes in the first decade of the ECB yields a positive appraisal of ECB monetary policy, particularly in light of the extraordinary initial conditions from which policy evolved.

\footnotetext{
${ }^{26}$ Christian Noyer: “We have a center, but the operations are made in the national central banks. We don't need to concentrate actions geographically (in contrast to the U.S. example in New York) because we have been born in a time of highly sophisticated telecommunication networks and computer systems, so it's easy to do that without concentrating the operations.”
} 


\section{$\underline{\text { Inflation Record }}$}

The inflation record is straightforward. Over the period since 2001 (assuming that ECB policy typically affects prices with a lag of about two years), HICP inflation has averaged 2.3\%, modestly above the ECB's official target of "less than, but close to 2\%.” During that period, headline inflation ranged from a trough of $1.6 \%$ in 2004 to a recent peak of $3.7 \%$ amid a record oil price shock. For comparison, in the pre-EMU period 1991-98, headline inflation averaged $2.6 \%$ and ranged from $0.8 \%$ to $5.0 \%{ }^{27}$ Even in Germany, which boasts the preeminent pre-EMU inflation track record, inflation has been lower and far more stable in EMU: Under the Bundesbank, German inflation averaged 3.4\% from 1965 to 1998 (with a standard deviation of 3.4\%), while German inflation since 2001 has averaged 1.8\% (with a standard deviation of only $0.6 \%)$.

The stability of euro-area inflation can be seen in the broad decline of its rolling standard deviation during the ECB years (see Figure 1). Other nominal variables, such as GDP, display a similar pattern. This remarkable steadiness is consistent with the evidence of reduced inflation

Figure 1. Five-Year Moving Standard Deviation of Annual HICP Inflation, 1976-2007

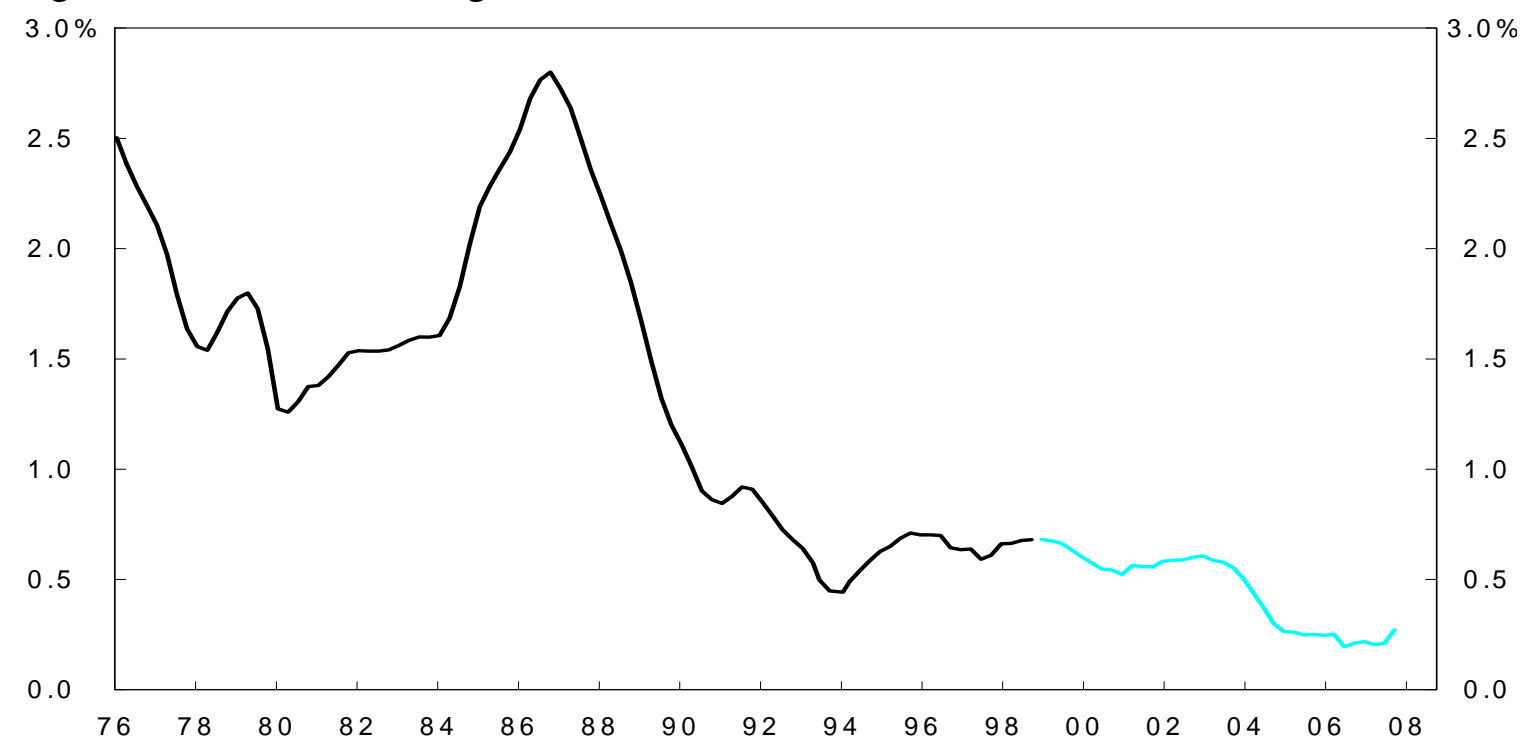

Sources: European Central Bank, Eurostat and authors’ calculations.

\footnotetext{
${ }^{27}$ Euro-area core inflation as measured by the HICP excluding energy and raw food averaged 1.8\% from 2001 to 2007 , remaining within the $1 \%-2 \%$ range in 71 of 86 months. By contrast, from 1991 to 1998 , core inflation averaged $2.9 \%$ and was in the $1 \%-2 \%$ range only 28 out of 96 months.
} 
persistence in many countries, including the largest euro-area members (see Cecchetti et al., 2008). Yet, this phenomenon should not be attributed primarily to external factors. Indeed, the Treaty's mandate and ECB commitments likely helped to embed this stability in long-term inflation expectations at an early stage.

Even prior to EMU, long-term government bond yields had converged to levels consistent with low euro-area-wide inflation, rather than to some weighted average of the yields of the high and low inflation countries (see Figure 2). By the start of EMU, the euro-area yield curve also appeared consistent with that of the yield curves of the lowest-inflation countries (see Figure 3).

Figure 2. Ten-Year Government Yields, Jan 90-Mar 08

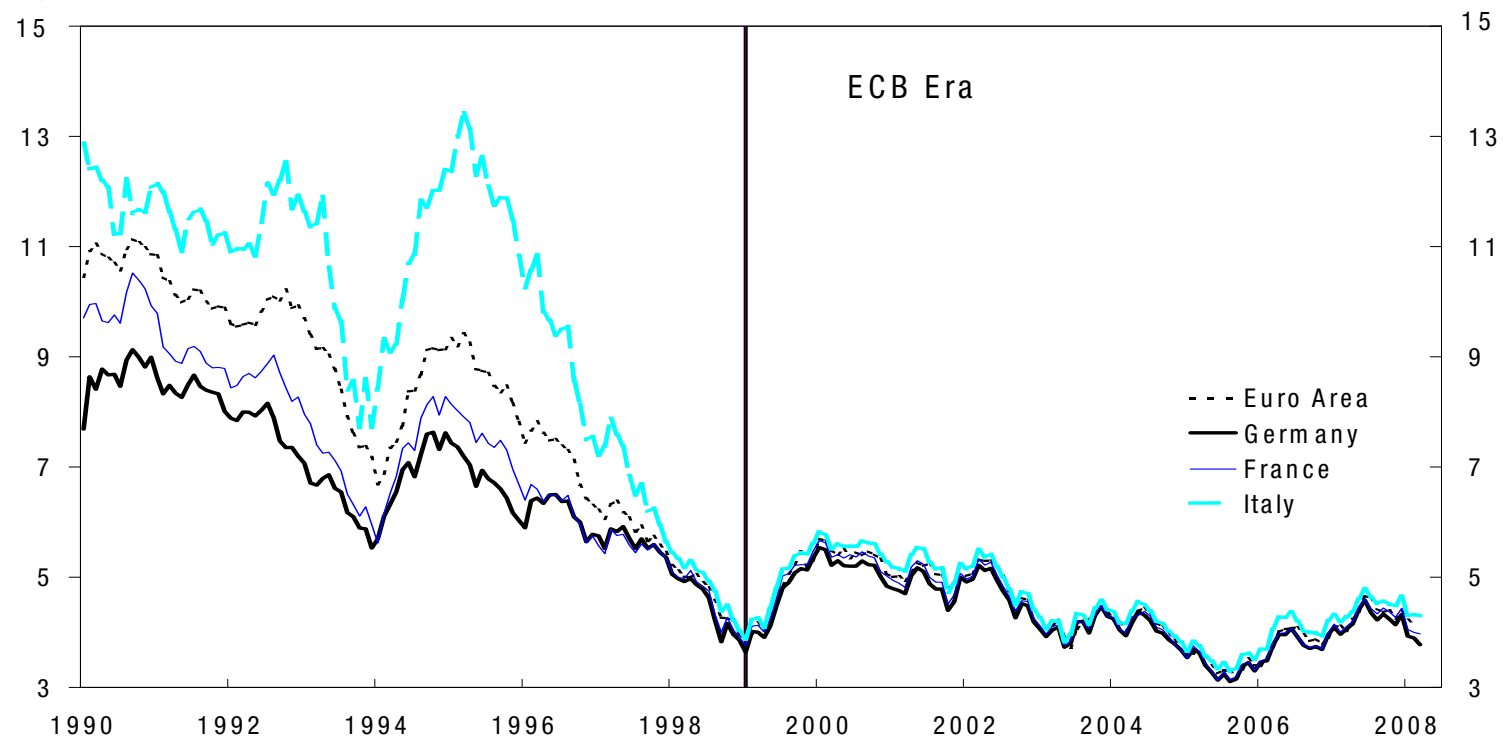

Source: Ecowin. 
Figure 3. Slope of Selected Yield Curves (10-year minus 2-year Govt. Yields), Jan 90-Mar 08

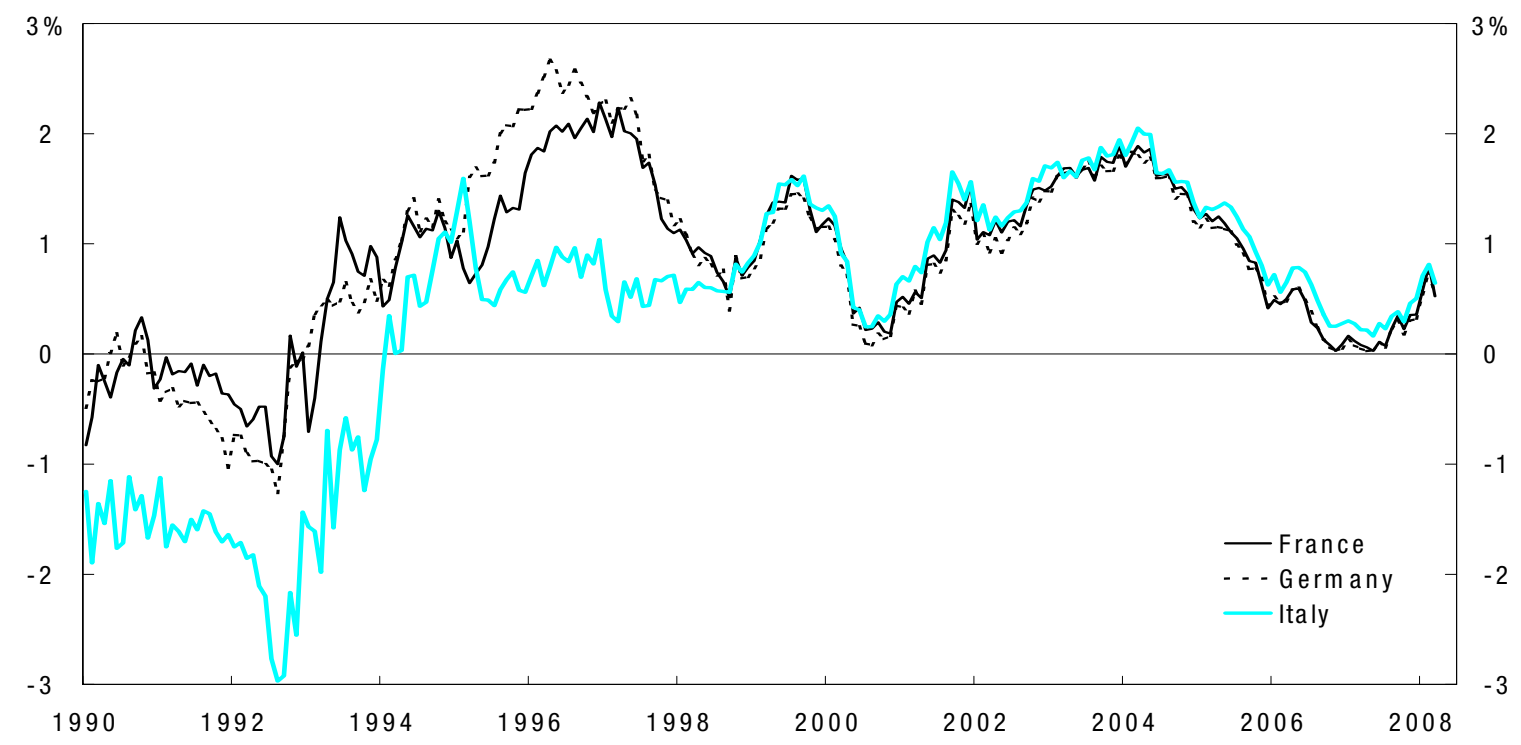

Sources: Ecowin and authors’ calculations.

This profound market confidence also is evident in the stability of inflation survey data, which has been anchored very close to the ECB's objectives. For example, the ECB's Survey of Professional Forecasters' mean projection of long-term inflation has been stuck, with the exception of a single quarter, in a tiny 1.8\%-2.0\% range since the survey began in $1999 .{ }^{28}$ Even the oil price shock of 2007-08 so far has failed to dislodge these expectations, while surveys of long-term inflation expectations in the United States have crept to the highest levels in more than a decade.

In light of the trying economic circumstances of the past decade, the achievement of low and stable inflation in the euro area most likely reflects good monetary policy, not good fortune. Several factors make this assessment compelling. First, since its inception, the euro area experienced large (and occasionally record) price shocks from developments in energy, commodity and currency markets - not unlike the Great Inflation episode. Second, the economy's persistent rigidities resulted in a low level of potential growth. ${ }^{29}$ Third, the loss of

\footnotetext{
${ }^{28}$ Andrew Crockett: "In some respects, the credibility of the ECB could be said to be even greater than that of the Federal Reserve. Inflationary expectations in the United States are further away from the so-called comfort zone of the Fed than European inflationary expectations are away from the ECB's target.”

${ }^{29}$ The following comment of Hans Tietmeyer is representative of views expressed by the majority of our interviewees: "My real disappointment relates to the domestic policies of some national governments, especially regarding inappropriate fiscal reforms and not creating appropriate conditions for more dynamic and flexible markets.”
} 
country-level monetary independence eliminated a potential remedy for idiosyncratic shocks. Fourth, rather than benefiting from fiscal reforms, the region exhibited fiscal fatigue (partly reflected in the relaxation of the euro area's fiscal compact - the Stability and Growth Pact, or SGP). Finally, the ECB endured repeated interventions by various regional politicians that might have weakened the credibility of a central bank less ardently committed to independence and price stability. ${ }^{30}$

Some outside observers have criticized the ECB for exceeding its inflation objective, and for not re-setting its objective in line with actual practice on the occasion of the 2003 policy review (see Galí et al., 2004). During the deflation scare, others suggested that the target was set too low to allow for efficient cyclical and competitive adjustments in some regions without favoring a disruptive decline of prices and wages (see European Economic Advisory Report, 2003). Our own judgment is that while the lingering asymmetry of the ECB's objective may not be optimal, in the absence of any credible deflation threat it is unimportant. It seems fair to conclude that the ECB has been very successful - at least until 2008 - in keeping inflation stably close to its goal over the first decade. Considering the uncertainties and doubts that preceded the ECB's existence, EMU skeptics must view this achievement as stunning. More important, low nominal bond yields and reasonably stable wage-setting in the face of record commodity price shocks confirm that capital and labor markets have confidence in the ECB's low-inflation commitment.

\section{Dividends of Price Stability}

Consistent with the Great Moderation literature, Cecchetti et al. (2008) note that the stabilization of euro-area inflation has been associated with a continued low level of output volatility compared to the Great Inflation period (see Figure 4). As just mentioned, the plethora of shocks that hit the euro-area economy in this period appears to undermine claims that this outcome is merely a result of good fortune. The largest shocks include the bursting of the global equity bubble, global recession, terrorist attacks, war in Iraq, a deflation scare that triggered unusually

\footnotetext{
${ }^{30}$ On this point, our interviewees were unanimous: On no occasion did the ECB alter policy as a result of strains with European politicians. Lucas Papademos: "My colleagues and I are very attached to the principle of central bank independence. Appropriate monetary policy decisions are best taken within an institutional framework that effectively safeguards this independence. Attempts by political leaders to influence ECB decisions will either have no effect or they may be counterproductive.”
} 
low global policy rates, and large currency swings. Yet, the low level of euro-area GDP volatility compares favorably even with the widely acknowledged U.S. example (see Figure 5). Under the ERM regime of the early 1990s, large changes in the value of the U.S. dollar had occasionally created stresses across European bond markets and cross-exchange rates that added to output volatility. The single currency regime appears to have counteracted such stresses. We agree with Cecchetti et al. (2006) that improved policy under the ECB shifted the euro area to a better tradeoff between the variability of inflation and the variability of output.

By securing price stability, ECB policy contributed indirectly to many other advances in euroarea welfare. One example is the progress in capital markets and the financial system.

Government bond markets appear to have been largely integrated at a very early stage in EMU. Legal and other obstacles still inhibit the integration of some markets, especially for corporate equities. However, the rapid expansion of markets for corporate bonds and for many derivative

Figure 4. Five-Year Moving Standard Deviation of Real GDP, 1976-2007

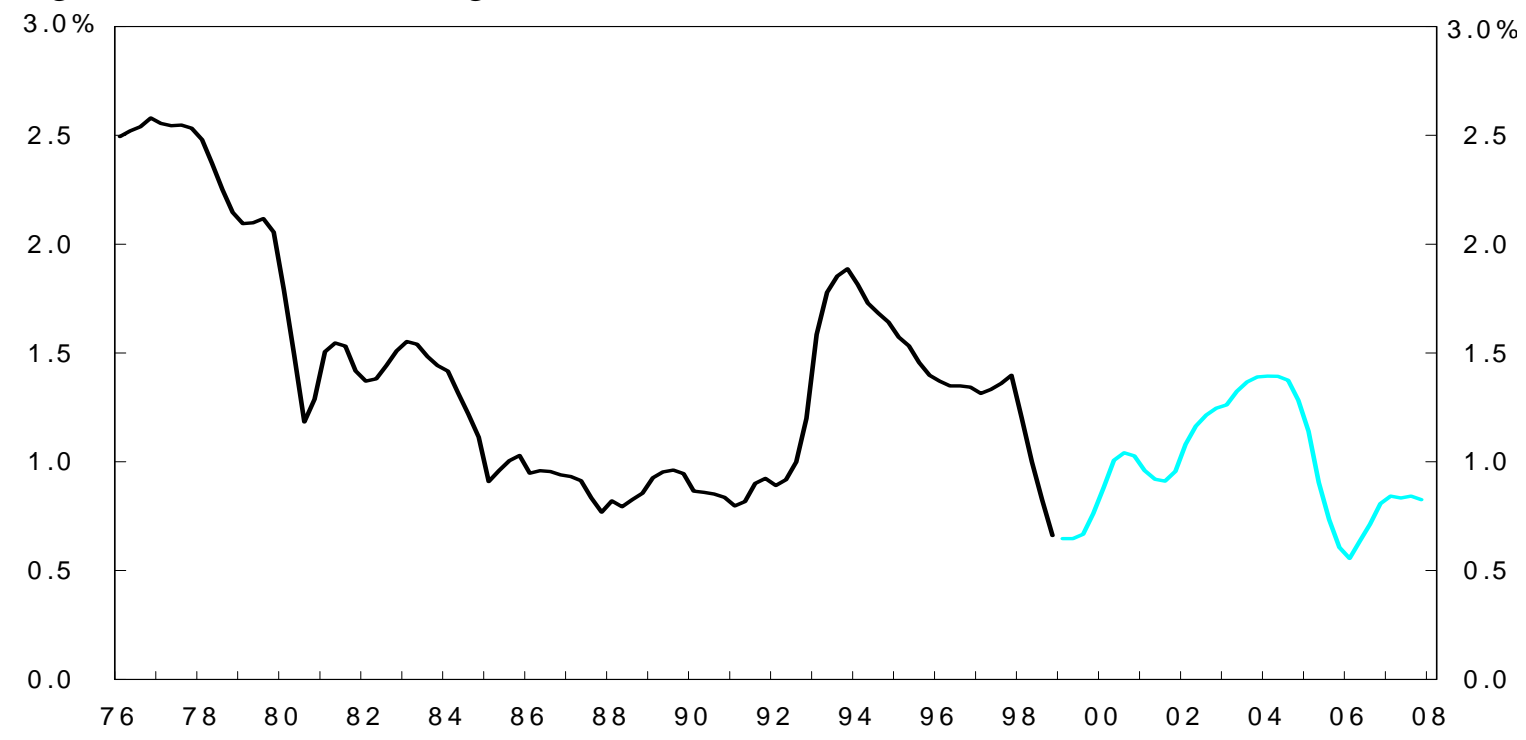

Source: European Central Bank and authors’ calculations. 
Figure 5. Real GDP Volatility - Ratio of Euro Area to United States, 1976-07

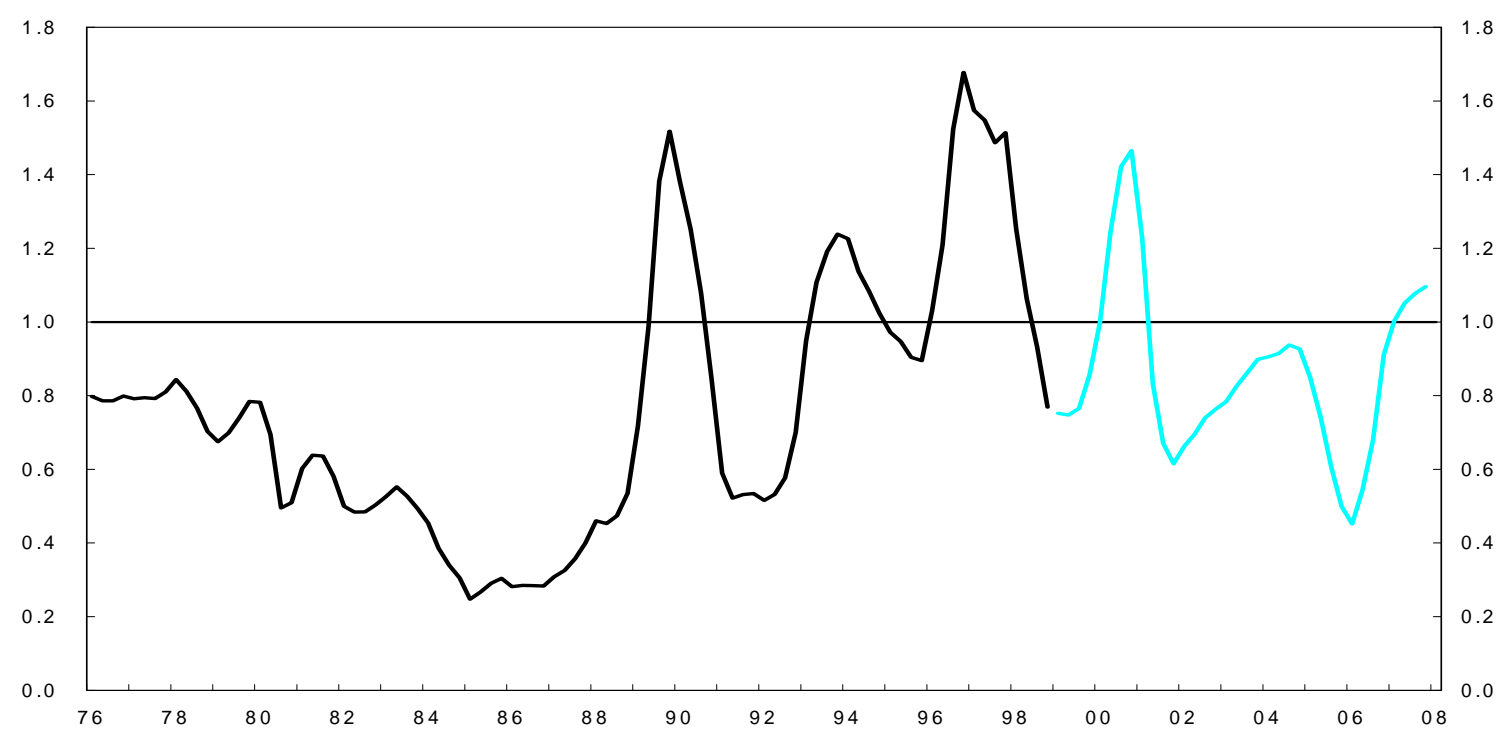

Sources: European Central Bank, U.S. Bureau of Labor Statistics, and authors’ calculations.

instruments over the past decade partly reflected the stable euro-area economic environment. The breadth and depth of these markets facilitate the efficient allocation of savings in the region. The gradual evolution toward banking integration also contributes to regional efficiency.

\section{Monetary Pillar: Did it Matter?}

One issue that may affect future policy strategy is the performance of the monetary pillar in the first decade. ${ }^{31}$ Compared to the $4.5 \%$ reference value for M3 growth set at the start of EMU, M3 growth averaged $7.4 \%$ since 2000 and exceeded the reference value in 88 out of 97 months (see Figure 6). Because the overshoot did not prevent the ECB from achieving a high degree of price stability, one may safely conclude that it did not prompt the ECB to become overly restrictive.

From this pattern, it is clear that the ECB's use of its monetary pillar has been far from mechanical. ECB policymakers, notably Issing (2004) and Stark (2006), have emphasized that the prominent role of money in their strategy aims at underscoring policy's “medium-term

\footnotetext{
${ }^{31}$ Alexandre Lamfalussy's comment is representative of the views inside the ECB in the early days: "I have always been in favor of the two-pillar approach in terms of strategy. I use economic analysis and then cross check it by examining the monetary aggregates.”
} 
Figure 6. Annual Growth of M3 (three-month centered moving average), 1999-2007

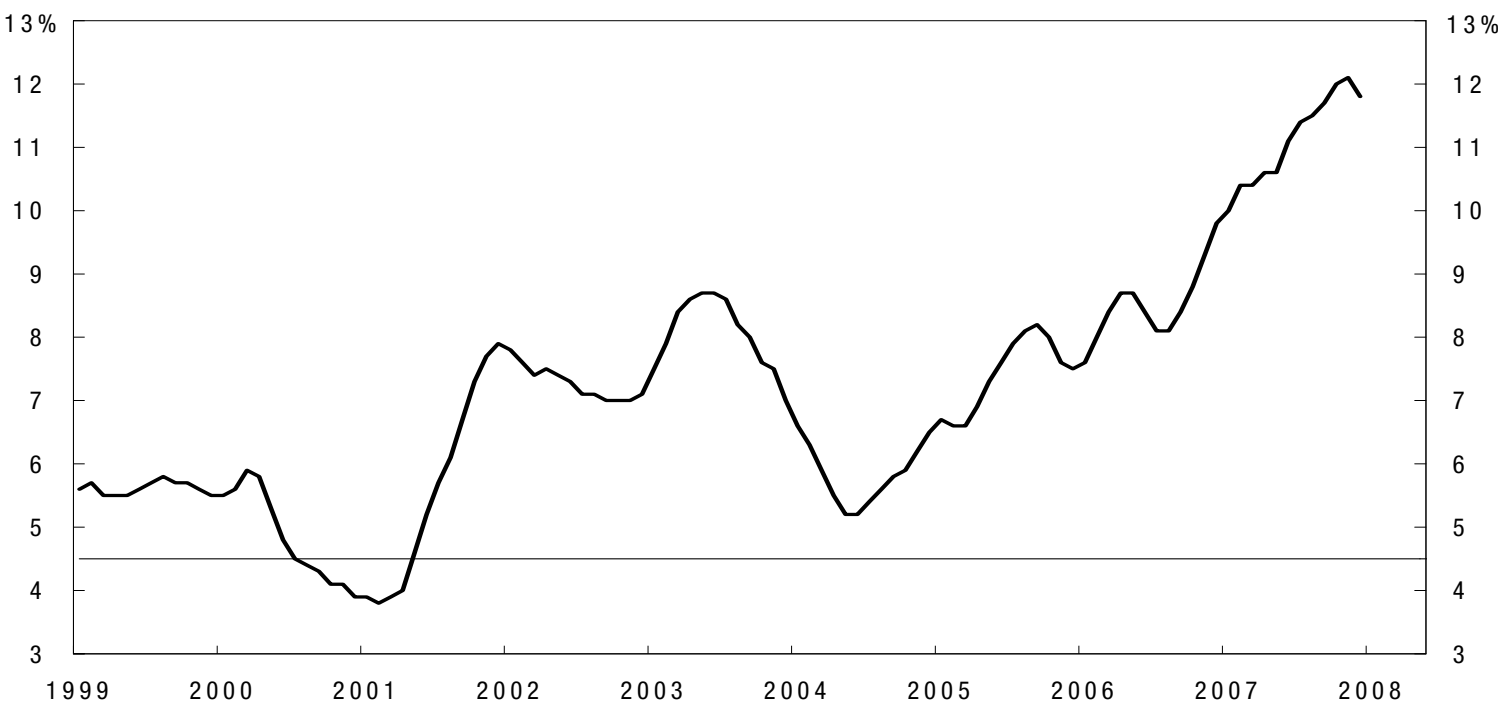

Source: European Central Bank.

orientation,” while taking account of the potential links between money and credit growth and asset price bubbles. ECB staff research (Fischer et al. (2006)) discusses the complex and evolving analysis that the central bank devotes to monetary developments as a "cross check" for other inflation indicators.

However, the complexity of the procedure - which involves the estimation of underlying trends in monetary aggregates adjusted for portfolio shifts -- likely makes any policy response to monetary developments less predictable. Without adjustments to the aggregates, money-based forecasts typically overpredicted inflation, while the adjustments may be large and occur with some time lag. In turn, market uncertainty about the ECB's response may reduce the effectiveness of policy, because ECB behavior is less likely to be reinforced by market anticipations. For example, Andersson, Hansen, and Sebestyén (2006) found euro-area bond markets to be insensitive to news about M3 announcements. To the extent that the ECB actually responded to monetary news, the response appears to have been received in the euro-area bond market as an unanticipated policy disturbance, despite the prominent role of the monetary pillar. In this sense, the pillar has yet to be defined in an operational manner that elicits market understanding. 


\section{Currency Considerations}

The performance of the ECB cannot be divorced from the role of the new currency, which instantly became the world's second-most important store of value and means of payment and has continued to rise in importance since inception.

The fluctuations of the foreign exchange value of the euro during its first decade of life are surely relevant for future policy strategy. Prior to EMU, some observers expected that the reduced importance of the currency for euro-area-wide activity would downgrade its impact on policy, hinting that currency volatility versus the dollar would rise compared to, say, the Deutsche Mark. In fact, there is little direct evidence of increased volatility (see Figure 7). Taking January 1999 as a base of 100, movements in the real euro/dollar exchange rate have been large, ranging from an index trough of 83 in 2008 to a peak of 139 in 2001, but the order of magnitude of these swings does not appear out of line with patterns in some earlier periods (see Figure 8).

Figure 7. Three-Mth. Mov. Std. Dev. of Euro/US\$ and DM/US\$ Exchange Rates, Jan75-Mar08

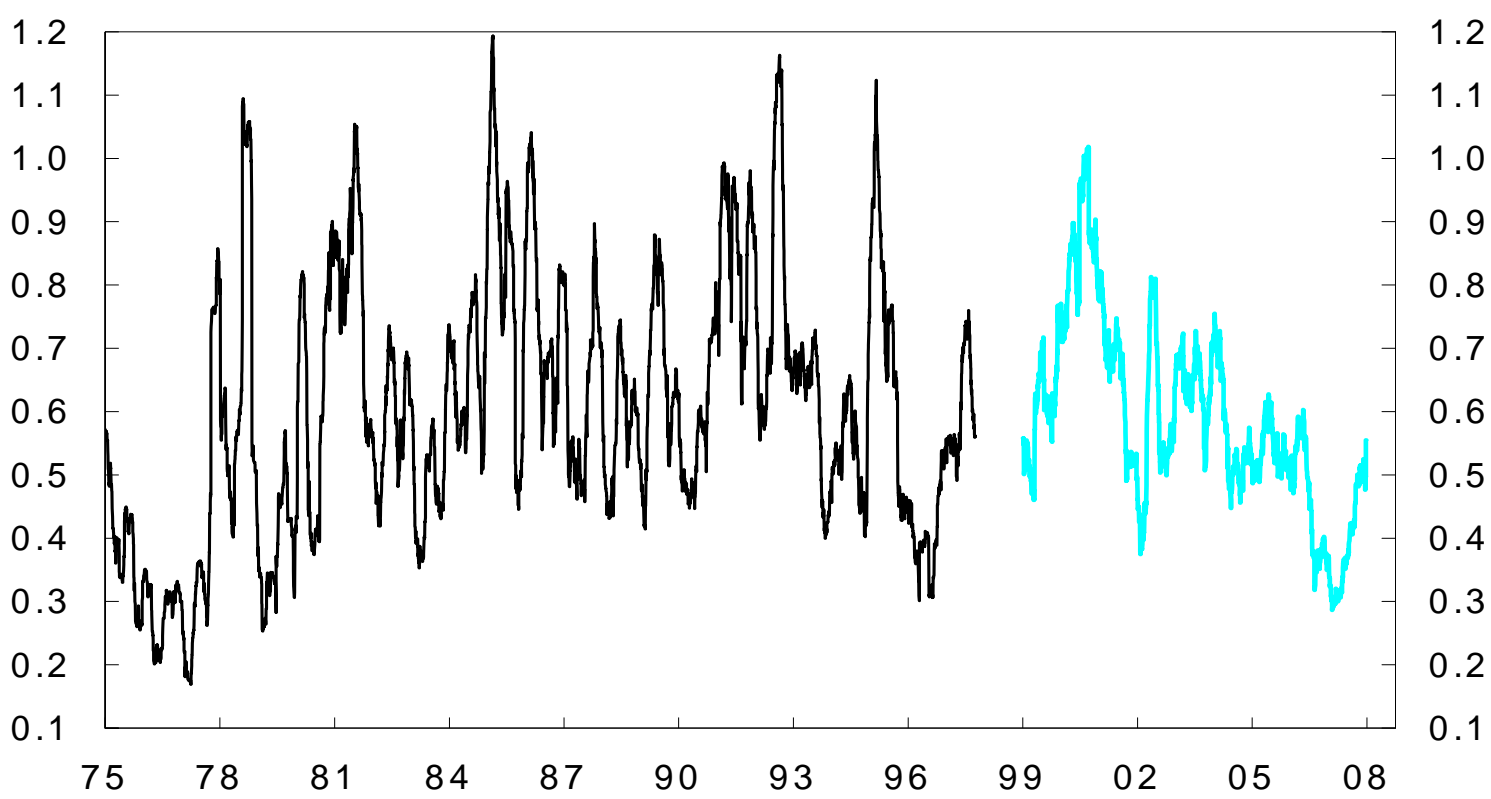

Sources: ECB, Federal Reserve, and authors' calculations. 
Figure 8. Inflation-Adjusted Euro/US\$ and DM/US\$ Exchange Rates (Jan 99=100), 1970-Feb 08

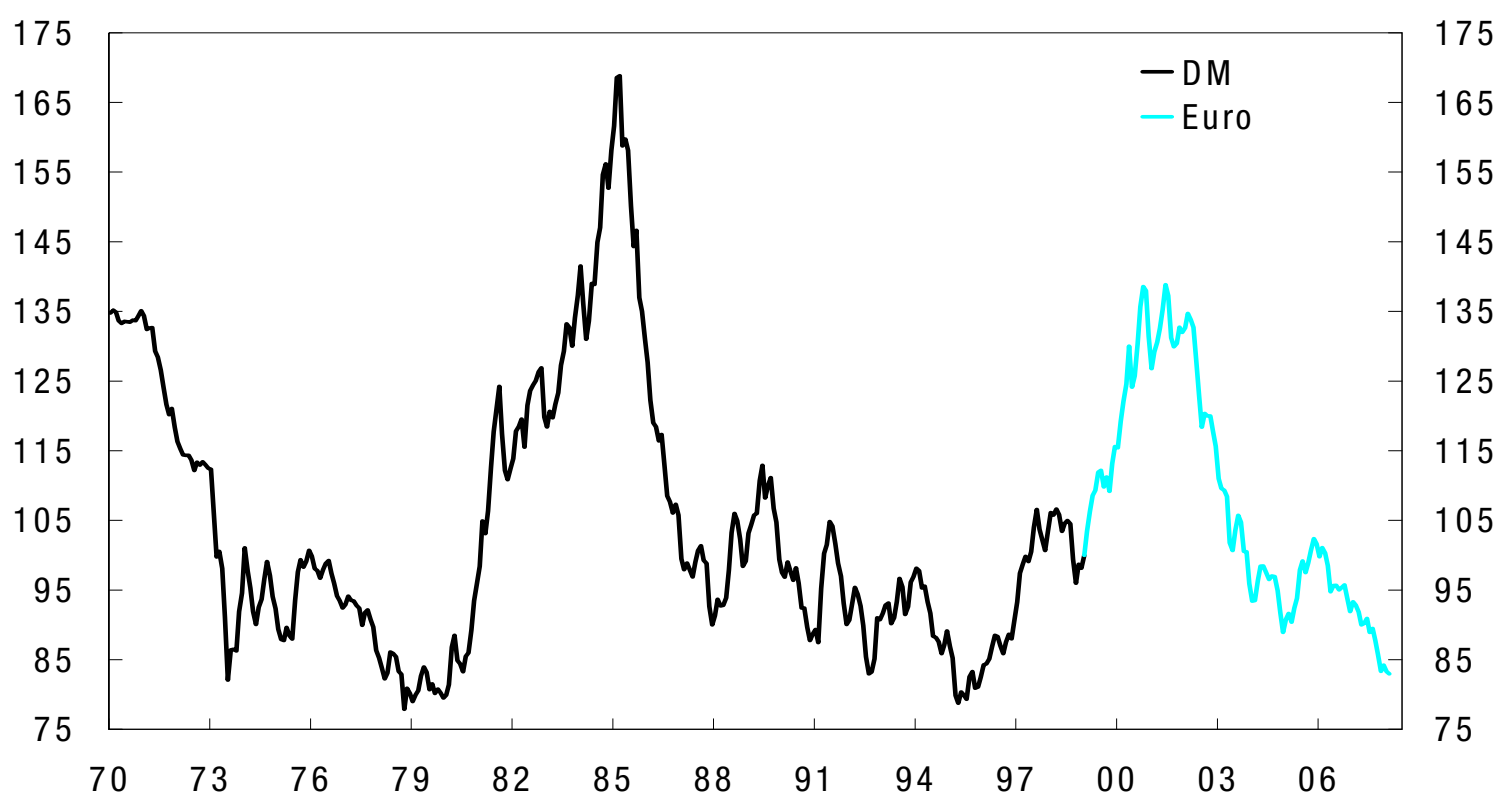

Sources: Deutsche Bundesbank, European Central Bank, U.S. Bureau of Labor Statistics, and authors’ calculations.

Broadly speaking, the ECB in its first decade has been as inclined to intervene directly in currency markets as the Federal Reserve (or U.S. Treasury); which is to say, not very. ${ }^{32}$ From an operational and international coordination perspective, our interviewees highlighted the flexibility that the ECB demonstrated in joint operations to support the euro in its early years. Yet, direct market intervention was rare: Multilateral intervention occurred only once (on 22 September 2000), when there was a clear sense that the euro was undervalued. While unilateral intervention may have taken place on other occasions, we are aware of only one instance (on November 3, 2000) that was reported in the ECB's Monthly Bulletin. Verbal intervention was more frequent, but one study viewed early statements by ECB officials as merely adding to currency volatility, with little persistent impact on the exchange rate (see Jansen and de Haan (2003)). In recent years, ECB officials occasionally have jawboned in an attempt to slow the euro's rise, but have not capped the climb. In real, trade-weighted terms against a broad range of currencies, the euro has appreciated by about 5\% from its start in 1999 and by $28 \%$ from its trough in November 2000.

\footnotetext{
${ }^{32}$ See Bini-Smaghi (2007) for a discussion of Eurosystem intervention policy.
} 


\section{Disappointments: Outside the ECB}

The most frequently expressed disappointments about the euro area in its first decade have nothing to do with ECB monetary policy per se: namely, the lack of structural and fiscal reforms and the lack of concomitant progress toward political union. ${ }^{33}$ Many of our interviewees contrasted the European Union's ambitious Lisbon Agenda with the scattered, desultory character of actual supply-side reforms and the frequency of backsliding. Some expressed concern that the region's low potential growth would lead observers to blame the ECB because of the need for policy to tighten even at early stages of recovery. Judgments about fiscal policy have been less negative than pre-EMU skeptics feared, but the lack of consolidation in some high-debt countries remains notable, especially amid renewed divergence between several national economies (see Figure 9). The relaxation of the SGP and the decentralization of the region's fiscal arrangements only add to doubts about coordination and the prospects for future consolidation.

Figure 9. Selected EMU Members: Changes in Current Account Balances (Share of GDP) and Unit Labor Costs (Percent), 2007 vs. 1998

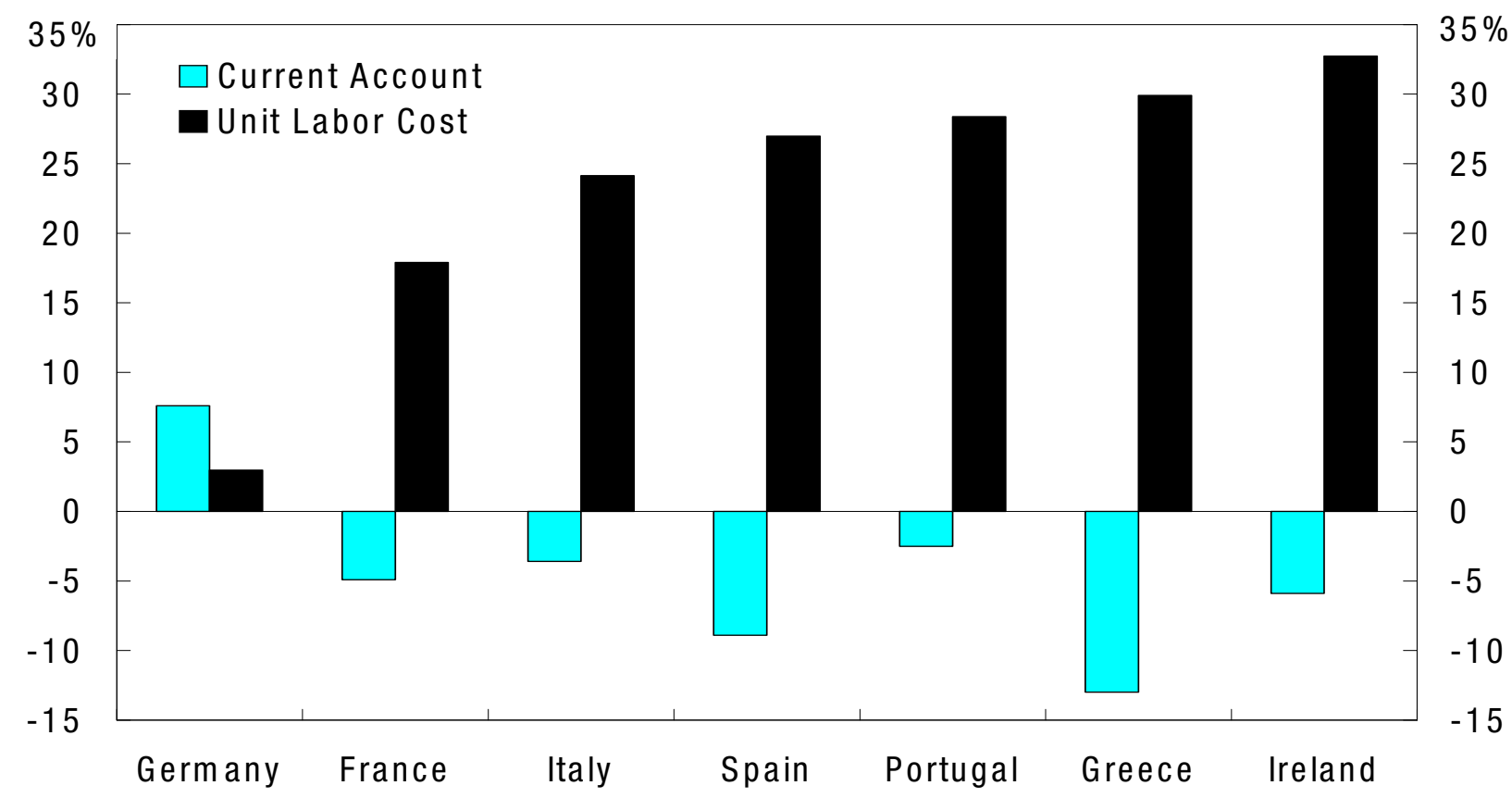

Source: EU Commission Ameco database.

\footnotetext{
${ }^{33}$ An indicative quote comes from our interview with Edward George: “[T]he problem is not the functioning of monetary union in a narrow sense, but the performance of the wider economy given the lack of political consensus that I think you need for successful economic management.”
} 
In contrast to what many EMU advocates anticipated, there is little doubt that progress toward political union has not kept pace with monetary union. ${ }^{34}$ From the ECB's perspective, this pattern complicates efforts to secure broad popular support. In a democratic society, public backing is critical to ensuring the independence of a central bank over the long term. While the Maastricht Treaty provides the ECB with a very strong foundation, the ECB lacks the natural constituency that the most credible national central banks typically enjoy, especially when confronted by politicians with a shorter horizon. The ECB's efforts to communicate help to build that popular support, but this process may take decades and will almost certainly be less rapid than in a period of speedier progress toward political union. ${ }^{35}$

\section{The Challenges Ahead}

Over the next decade, the ECB will face many of the policy challenges common to all major central banks. From time to time, it will need to reassess and refine the strategy employed to secure its Treaty-mandated objectives. It will need to improve its models of the euro-area economy, taking account of structural changes induced by the integration of Europe and by trends such as global economic and financial integration. It will need to advance the frontiers of research and central bank practice to understand how asset prices and other financial developments should be integrated into policy decisions. Most obviously, it will need regularly to reassess the outlook for price developments and to re-calibrate its policy stance consistent with its objectives and strategy. As a lender of last resort, it will need to manage liquidity when crisis threatens. To foster accountability and make policy effective, it will need to communicate its understanding and its policy thrust to the public at large. Finally, it will need to cooperate with policymakers outside the euro area to address issues of mutual interest, ranging from financial stability to exchange rate developments to the operation of official international financial intermediaries. These issues are of great interest, and we expect that the ECB will make important contributions to global "best practice," while also benefiting from the successes of other central banks.

\footnotetext{
${ }^{34}$ Axel Weber: "Regarding disappointments, in contrast to my initial expectation as an outside observer, the creation of EMU did not have a significant impact on further political unification in Europe. The catalytic role of the euro, not just in financial markets but also in the political sphere, was something that I expected to gain some stronger momentum in the first 10 years. Looking back, it hasn't.”
} 
In the remainder of this paper we focus on challenges for the ECB that differ substantively from those facing other major central banks. The concerns identified by our interviewees as likely to pose special challenges for the ECB exhibit some variation, but two stand out: (1) enlargement; and (2) the complex framework for addressing financial instability. A variety of other matters received attention, but less broadly. These include the need to develop and secure a popular basis for the ECB; the need to manage a low-growth region facing competitiveness challenges and regional divergences; difficulties of fiscal coordination; and potential conflict over currency matters with ECOFIN; among others. We address each of these in turn.

\section{Enlargement}

Jean-Claude Trichet: "We are 27 countries in the European Union. In the euro area, we are 15. Of the 27, 25 have no opt-out clause. The challenge is to progressively absorb all the newcomers: none of them has an opt-out clause. At the same time it is imperative to preserve the credibility of the euro area as a whole by strictly respecting the conditions of entry, the Maastricht criterion.”

Otmar Issing: "It was extremely important to have an automatic rule which determines who will vote when. That rotation rule is in place and can be applied when the number of members reaches 21. Discussion rules can be changed anytime. New people will find reasonable solutions."

Lucas Papademos: "As the euro area expands and the number of Governing Council members increases, it may be more efficient to take decisions by voting rather than by forging a consensus as is presently the case."

Enlargement will affect the euro area and the ECB in many ways. By virtually any metric, it will add to the region's diversity (whether the focus is on language, culture, or legal systems). From an economic perspective, a 25-country currency area will form the world's largest in terms of GDP, with a population of about 500 million, compared to around 300 million in the United States. The ratio of per capita incomes between the richest and poorest members would widen to nearly 13 from less than 4, based on recent data (see Figure 10). ${ }^{36}$ The speed of integration of product, labor and financial markets may quicken, accelerating structural change. And each new euro-area member will bring with it a new fiscal agent and a parliament. Among other things,

\footnotetext{
${ }^{35}$ Philipp Hildebrand: "[T]he big challenge for the ECB remains that it does not have a natural (or national) constituency in the population.”
} 
this expansion will increase incentives for free-riding, thereby complicating any constitutional changes that would require unanimity.

Naturally, the need to assess the preparedness of prospective members will repeatedly revive the issues that confronted the European Council ahead of EMU: What degree of convergence has been achieved, and what is needed to satisfy the Treaty's provisions? Although we did not explicitly pose this question, our interviewees reported no reason to expect that convergence prerequisites would be relaxed in the future.

Against this background, the ECB has established a set of voting rules - essentially a rotation structure for NCB governors that resembles the voting practices of the U.S. Federal Open Market Committee. In this sense, the ECB is well ahead of other political structures in the European Union - including the European Council and the ECOFIN - that also may experience stress as their membership becomes larger and more diverse.

Figure 10. European Union: Per Capita Income by Country (Euro Area Average = 100), 2007

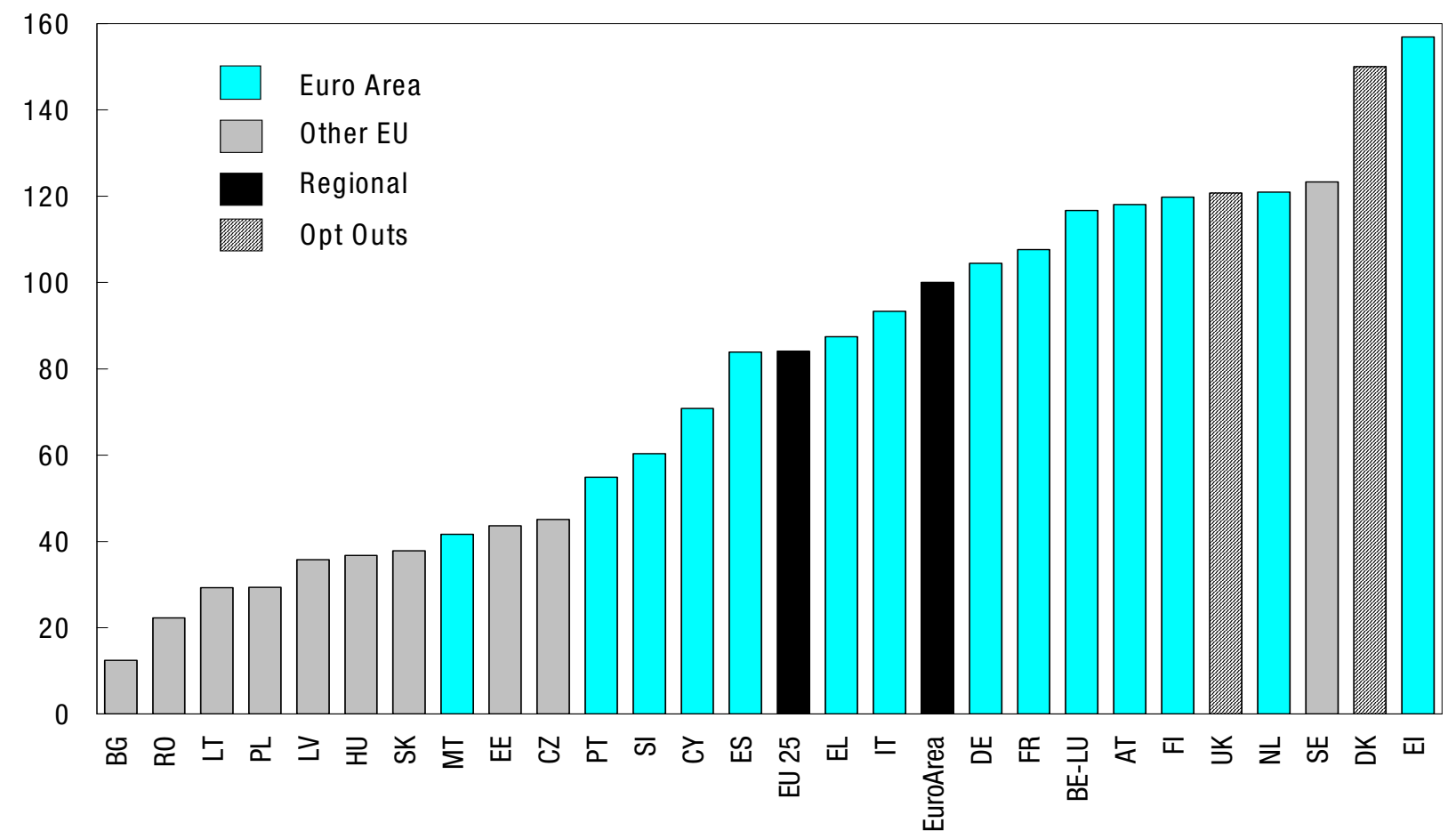
Source: IMF.

\footnotetext{
${ }^{36}$ This calculation excludes Luxembourg, which has the euro area's highest income per capita.
} 
Nevertheless, in the absence of further reforms, enlargement threatens to make the ECB less nimble. ${ }^{37}$ The large number of voting parties (capped at 21 in December 2002), and the larger number of potential discussants in the Governing Council (which includes non-voting Governors), will tend to complicate decision making. If increased membership makes policy debates interminable, it may not take long for the Governing Council to adopt mechanisms for speeding discussion. Over time, efficiency considerations likely will boost pressures to shift from a "consensus" model to a voting model for making policy choices. ${ }^{38}$

The committee process, which still requires Frankfurt visits by NCB staff to achieve consensus and make decisions outside of the narrow arena of policy-rate determination, poses a greater challenge. Innovative approaches that delegate authority (or monitoring responsibilities) to subgroups that do not include all 25 national representatives may become more frequent. One past example of such cooperation has been the development of TARGET II undertaken by a subset of NCBs and then distributed to the Eurosystem as a whole.

Yet, it remains to be seen whether an increasingly diverse membership will be prepared to delegate authority across a broader set of tasks. How will the enlarged membership affect the consensus on issues such as the quantitative definition of price stability or on the policy strategy? How will ECB decision practices evolve? How will membership of the Executive Board evolve to reflect enlargement? Will it become more difficult to reach consensus on the appointments of top ECB officials? Will trends toward economic divergence for some existing euro-area members intensify or diminish as membership rises? How will the difficulty of coordination among 25 fiscal agents affect monetary policy? Will a larger number of more diverse members exposed to idiosyncratic shocks raise the chances of a national fiscal crisis, widen market yield spreads and, in the extreme, lead to a test of the Maastricht Treaty's "no-bailout” provisions?

\footnotetext{
${ }^{37}$ Philipp Hildebrand: "Making the institution function well as it enlarges will be a very big challenge. As the membership increases, at some point, there will be an inevitable need to look at institutional reform to make sure the organization can remain nimble and effective."

${ }^{38}$ The possibility of a future shift toward a voting model was mentioned by more than one interviewee.
} 
Enlargement will be a particular challenge in the area of communication. Even today, no other central bank faces the task of communicating with the public at large in 15 different countries. While the presence of NCB governors at the ECB is helpful, it is far from a panacea. As our interviewees observed, speaking to local governments or populations is fundamentally different than communicating with financial markets. As we noted earlier, the lack of synchronization in this effort in the early years of the ECB may have created market confusion on occasion. Regardless of their current cyclical circumstances, diverse national histories may prompt different constituencies to view identical policy statements as accommodative or restrictive. If the longest-run challenge of the ECB is to secure a popular base, as several interviewees suggest, then enlargement only intensifies that challenge. ${ }^{39}$

Against this background, we do not expect the ECB to publish minutes, detail the statements or votes of Council members, or announce an expected policy rate path anytime soon. However, policymakers may choose to consider other means of reporting on policy-related discussions that better reveal the range of Council views without inviting invidious political attacks against individuals. For example, information about the evolving strength or weakness of the policy consensus could affect forward-looking financial markets in a fashion that would enhance the effectiveness of policy.

Of course, the EU itself may expand beyond its current membership of 27. We expect that new entrants to the EU will wish to join the euro area at an early stage to secure the benefits of its credibility. Consequently, the enlargement challenge is both unique and open-ended.

\footnotetext{
${ }^{39}$ Beyond enlargement per se, several interviewees expressed concern that politicians and the public at large would forget how difficult life was before monetary union. Ignazio Angeloni: “Over time, I think that people will start forgetting the benefits and the advantages of belonging to the euro. They will forget how difficult it was to manage their own currencies. I am talking about particularly those that had unstable exchange rates. They will forget the times of high interest rates due to currency challenges. And they will start thinking that perhaps without the euro they can be better off. Unavoidably, I think there will be political elements in national politics that will try to exploit anti-euro public opinion sentiments.”
} 


\section{Financial Stability}

Jaime Caruana, "When I was going to Frankfurt as a central banker, my role was clear. I had to vote for the best monetary policy for the euro zone. When I participated in financial stability discussions, my role was clear: As the Spanish banking supervisor, my mandate in the Spanish law was to defend the Spanish banking system. I was accountable to the Spanish Parliament. Fortunately, protecting the Spanish banking system was consistent with protecting the European one, but I think that introducing some balance, some European mandate would be better."

Christian Noyer: "We need to have the same rules. Even if we had a single supervision authority, it would not solve the problem simply because there are differences in the regulations. The single authority would have to implement 15 different legislations of regulation. Unifying the rules is certainly the first thing to do."

Axel Weber: "We need an evolving European structure of banking supervision. When the banks become more international, more pan-European, so will banking supervision. This is an evolution that will become more important in the future."

Jean-Claude Trichet: "At this stage, what we are calling for is a close relationship - intimate cooperation between the banking surveillance authorities themselves, and very close links with the central bank, including a full transfer of information."

Our questionnaire (drafted in the spring of 2007) highlights concerns about the euro area's framework for financial stability that pre-dated the global crisis which began in August 2007. At this writing, that crisis is testing the industrial world's stability apparatus more broadly, intensively, and persistently than any prior experience in the postwar period, and certainly far beyond what any simulation or diagnostic stress test likely would achieve. As a result, the crisis has revealed important strengths of the euro-area stability mechanisms, but has not reduced our unease about vulnerabilities in this framework.

Because these concerns are largely shared by our interviewees, we are confident that the ECB will seek aggressively to approach "best practice" in this area, as it has in other matters. However, continued progress toward financial integration, in the context of a fragmented and complex stability framework, probably makes this goal the most important as well as the most difficult one for the ECB over the next decade. Failure to advance the stability framework which is a task that goes far beyond the limits of what the ECB alone can achieve - could involve large costs for the region as a whole and could reduce the competitiveness of euro-area financial centers. 
In the area of liquidity provision as a lender of last resort, recent experience has highlighted important ECB successes. In August 2007, the ECB boosted liquidity supply early and aggressively to counter sharp increases in funding rates as banks turned cautious and alternative private sources of funding shut down. The ECB's Bagehot-style marginal lending facility (MLF, designed to cap overnight rates in normal times) can be viewed as an automatic mechanism for calming liquidity fears in a crisis. ${ }^{40}$ In order to deliver liquidity effectively, the ECB utilized the broad flexibility that it enjoys with respect to assets that it may accept as collateral or acquire outright, including a variety of asset-backed securities. ${ }^{41}$ Beginning in December 2007, the ECB also cooperated with other central banks, including playing a role in distributing dollar liquidity to banks in its region.

As term euro rates surged, the ECB was compelled to engage in fine-tuning operations that supplied an extraordinary volume of liquidity, suggesting that intermediaries became reluctant in the crisis to use the anonymous MLF. The ECB's actions also did not prevent term money market spreads from widening in a persistent fashion once the crisis began in earnest. Unlike the Swiss National Bank, for example, the ECB did not alter its overnight rate target to stabilize term money market rates. The effect has been a tightening of money market conditions that policymakers did not explicitly seek.

Yet, the ECB could have avoided this outcome (by lowering policy rates) if it had wished to do so. The ECB's willingness to tolerate a rise in term money market rates (and to consider increasing the key rate on repurchase agreements) highlights the extent to which it has distinguished between the provision of crisis liquidity and the setting of policy rates. Moral hazard concerns still would arise if the ECB appears compelled to compensate for uncertainty about systemic vulnerabilities by generous liquidity provision. Even so, it seems fair to conclude

\footnotetext{
${ }^{40}$ Vitor Gaspar: “If you look at the functioning of the ECB's marginal lending facility and you compare with the prescriptions from Bagehot on the functioning of the lender of last resort, there should be no need for any ambiguity concerning the lender of last resort function. The lender of last resort is simply subsumed within the regular functioning of the operational framework." See also Gaspar (2006).

${ }^{41}$ See European Central Bank (September, 2006) for a description of collateral rules. We note that the Federal Reserve's liquidity-supply mechanisms have evolved during the crisis to become more like the ECB's both in terms of acceptable collateral and the range of counterparties.
} 
that the ECB's toolkit for liquidity supply has been crisis-tested and satisfies current "best practice" standards among central banks.

At the same time, other, potentially more troubling aspects of the euro-area stability framework have been brought to light in this episode. ${ }^{42}$ In contrast to liquidity matters - that lie clearly within the ECB's mandate - solvency matters are addressed exclusively by national institutions, which may have different views about what constitutes a systemic threat and about how and when public resources should be employed. ${ }^{43}$ The fact that there is no euro-area fiscal agent means that burden sharing across nations would be a challenge should a large (truly European, rather than national) institution become unstable. In many, but not all, euro-area countries, the NCB is the banking supervisor, but few NCBs also supervise nonbank financial institutions or securities markets. ${ }^{44}$ Rules for supervision are made at the country level, and have not been fully aligned across the euro area, despite the existence of some common financial directives. It is even conceivable that conflicts could arise between the national mandates of some NCB governors in their role as supervisors and the mandate imposed by the Maastricht Treaty in their role as members of the ECB Governing Council. ${ }^{45}$

As our interviewees stressed, there is little or no political will to replace this fractured supervision and crisis management framework with a more centralized one. In fact, it is not even clear that the presence of a single supervisor would successfully resolve the time-sensitive information and coordination problems that are inherent in financial crises. ${ }^{46}$ At present, even the largest financial institutions typically still have an identifiable national home, while mid-sized and small institutions usually operate locally and can be monitored by an expert familiar with

\footnotetext{
${ }^{42}$ For a view that regulatory competition contributed to recent financial excesses, see Tabellini (2008).

${ }^{43}$ Several interviewees expressed concern about the difficulty in identifying insolvency.

${ }^{44}$ It also remains to be seen how the ECB and an NCB, which implements any lending to specific institutions, would balance the needs for overall monetary control and for liquidity supply to a troubled institution should its requirements be large.

${ }^{45}$ In the recent crisis, there was one potential institutional risk that reportedly was conveyed to the ECB only after the risk had subsided and shortly before it became public.

${ }^{46}$ While there was substantial disagreement among the interviewees over the desirability of a pan-European regulator, even those in favor of consolidation expressed doubts that such an institution would come into existence any time soon. Several respondents did suggest a certain inevitability in the process: Jaime Caruana: "I stated publicly when I was [at the Bank of Spain] that either we would find a system that works like a one-regulator system in Europe, or we will end up having one regulator in Europe.”
} 
local conditions and traditions. Finally, no supervisor anywhere has the means to address the costs of insolvency. ${ }^{47}$

Against this background, many interviewees favored a gradual, long-term shift toward greater supranational supervision, particularly as financial integration advances. However, there was a strong practical consensus that for the foreseeable future the ECB should aim to help the existing highly decentralized system become sufficiently effective so that it can act as one in a crisis.

Crisis management in a decentralized system is a daunting challenge that will require the cooperation and support of many policymakers - including legislatures - to limit the potential damage to the euro area from a financial crisis. In this context, the ECB has sought to cooperate closely with European supervisors to ensure the timely flow of information to decision makers in a crisis. ${ }^{48}$ Even when the supervisory function is performed by an NCB - directly ensuring the Eurosystem's involvement - the timely flow of information necessitates a well-defined set of procedures and practices that are understood in advance. For example, the central bank's reputation could be put at risk if an insolvent institution were able to exploit the marginal lending facility (even temporarily) because the ECB lacked knowledge of the circumstances.

In recent years, the ECB has helped prepare for episodes of financial instability by promoting cooperation among supervisors and the central bank. ${ }^{49}$ The Committee of Bank Supervisors, which meets at the ECB, is one example. The ECB also has been a party to Memorandums of Understanding (MoUs) with supervisors and fiscal agents that promote cooperative behavior and help clarify responsibilities in a crisis. And, the ECB has cooperated with supervisors in simulation exercises or stress tests to prepare officials for a crisis. Going forward, the ECB can seek to promote a unified, best-practice approach among supervisors in collecting and assessing information about the institutions under their purview. Such a common methodology - akin to

\footnotetext{
${ }^{47}$ Fabrizio Saccomanni “There is obviously great concern by political leaders that they may be confronted with a 'European' financial crisis of which they know nothing and for which they might be required to bear a financial burden that would involve taxpayer money." Andrew Crockett: "It is not clear what would happen in the event that a substantial-sized European financial institution got into life-threatening trouble.” Jean-Claude Trichet. "There is no taxpayer money at the level of Europe as a whole.”

${ }^{48}$ Alexandre Lamfalussy: "In crisis management situations, the flow of information is extraordinarily important and there is a natural tendency of each group who possess information to hold it back as long as feasible. That's instinct: Hand it over only when necessary. This is not helpful, so here we might have a problem.”

${ }^{49}$ See the relevant articles in the ECB Bulletin (2004 and 2007).
} 
the guidelines and materials developed by the Federal Reserve for the supervisors in its District Banks - would appear to be a prerequisite for efficient information flow in a crisis. ${ }^{50}$

The ECB, like any lender of last resort, has to be concerned lest its preparations and plans for addressing crises prompt moral hazard. Even so, some interviewees thought that the complexity and decentralization of the stability framework favored the development of a "handbook" for crisis response combined with clarity about the chain of command in a crisis. Agreement on such a structure would require the mutual assent of many parties, because it is not set in law as a euroarea standard. Without it, however, policymakers may not know who is in charge. Moreover, the lack of accountability would diminish the incentives to manage effectively. The task of balancing such preparations and crisis flexibility against moral hazard risks is difficult even where the crisis chain of command is clear, but seems even greater where it is not.

Managing a future crisis also could be complicated by differing national legal mechanisms and procedures. For example, euro-area members have different practices with regard to deposit insurance, bankruptcy and even court procedures. There also is no common approach for early public intervention in the case of a troubled financial institution, such as the procedures for "prompt corrective action" in the United States or the proposed "special resolution regime" in the United Kingdom. ${ }^{51}$ A credible threat of early intervention creates incentives for financial institutions to guard their capital and, thereby, limits systemic risks. Early intervention rules also could reduce "home-host" strains that may arise when banks compete in other national markets by narrowing the uncertainty of host supervisors about the workout procedures and the availability of capital in a crisis. As U.K. policymakers learned from the Northern Rock episode, the lack of an early intervention mechanism can leave policymakers with a painful choice between acquiescing to heightened systemic threats from a bank run or to moral hazard-inducing bailouts of shareholders, debt holders and management.

\footnotetext{
${ }^{50}$ In a recent assessment of the financial stability framework, the Eurosystem concludes that "supervisory convergence is a key objective.” See "Review of the Lamfalussy Framework: Eurosystem Contribution,” November, 2007.

${ }^{51}$ For details of the United Kingdom's proposed special resolution regime, see Bank of England, HM Treasury, and Financial Services Authority (2008). When asked whether an early intervention scheme was needed in the euro area, Jaime Caruana responded that there is a clear need for "some kind of early intervention system where the rules are clear and you know that you have to act rapidly at the beginning.”
} 
Naturally, enlargement will add to the complexity of the euro-area stability framework.

Accordingly, the ECB also may wish to encourage prospective new members to implement best practice rules and procedures in this area as they prepare for accession to the single currency.

\section{Other Distinguishing Challenges}

Otmar Issing: "What is unique for the ECB is the complex environment. For any central bank, be it the Bundesbank, Banque de France, or the Federal Reserve, the support of the people is crucial. But, the ECB still is a young institution, and the euro area is very complex, not least due to the language and communication problem.

Sirkka Hämäläinen: “There are many signs of weaker political commitment: unwillingness to meet the commitments of the Stability and Growth Pact, attacks on the independence of the ECB, or the lack of measures for structural improvements. Monetary policy needs strong political support to be effective."

Enlargement and financial stability are not the only issues that are likely to affect the ECB differently over the coming decade. The list of unique challenges identified by our interviewees is substantial, and includes popular attitudes toward the central bank, potential for regional divergences in a low-growth region, coordination with fiscal agents, response to currency disturbances, personnel selection, and operational efficiency. In this section we briefly discuss a few of these.

\section{Broadening the Popular Base}

Before the Maastricht Treaty was enacted, critics sometimes spoke of a "democratic deficit” to describe a perceived lack of grassroots support for and involvement in the political (and monetary) integration that European leaders sought to realize. This legacy, combined with the complexity of euro-area and European governance, boosts the importance of ECB transparency and accountability. Over the long term, no central bank can operate in a truly independent fashion without a modicum of popular support for its objectives and methods. In the case of the ECB, the broader the popular support, the more its policies are likely to appear credible and resilient (and, as a consequence, prove effective). 
As previously highlighted, the ECB uses many means to address its diverse constituencies and to garner support. Going forward, if necessity is the mother of invention, the ECB is likely to be at the forefront in improving central bank communications, because the challenges that it faces are notably greater and more enduring than at other central banks. As our interviewees emphasized, communication in multiple languages and across cultures and traditions is inherently complex, and will become increasingly so as the euro area enlarges. Some national politicians also may view the ECB as an easy target, because it lacks a national constituency that would raise the political costs of ECB-bashing. ${ }^{52}$ At some stage, effective ECB policy will conflict with the short-term interests of particular countries or their policymakers. Reduced momentum toward political integration in Europe also exposes the ECB to potential backlash against policy centralization, even when changes in the economic environment - such as increased financial integration - favor coordinated responses. ${ }^{53}$

\section{Suboptimal Currency Area}

Critics of the Maastricht Treaty bemoaned the lack of European fiscal and labor market flexibility long before the ECB was established. If anything, the track record of EMU's first decade has resulted in less economic and fiscal divergence than many observers, including some interviewees, had feared. However, risks remain because potential growth is low, labor markets are relatively rigid, and there is little scope for fiscal burden-sharing. Moreover, as Papademos (2007) describes, some countries - including Greece, Italy and Portugal - exhibit divergent trends in the growth of unit labor costs that appear to diminish their competitiveness. Widening current account imbalances are a symptom of this competitiveness problem (see Figure 9).

The ECB cannot alter its policy rate for the purpose of limiting economic divergence or to boost growth sustainably above potential. Nevertheless, both divergence and low potential growth add to the strains associated with stability-oriented monetary policy, making ECB policies less

\footnotetext{
${ }^{52}$ Philipp Hildebrand: "Politicians face a relatively low cost for attacking the ECB compared to the cost they would face in attacking a similarly credible national central bank."

${ }^{53}$ Axel Weber: "I think politicians very often forget the merits and the advantages of having independent central banks guaranteeing price stability and have not lived in periods where they see the downside effects of high inflation on the economy.”
} 
popular and less credible. ${ }^{54}$ In the extreme, economic divergences can prompt a regional fiscal crisis that might test untried portions of the Maastricht Treaty, such as the "no bailout" clause. While such a test currently seems a remote possibility, it cannot be ruled out over the long run.

\section{Coordination with Fiscal Agents}

In the first decade of EMU, contrary to pessimistic expectations, there were no fiscal crises, and the excessive deficit procedures that began in recession mostly have been wound down as deficits narrowed cyclically. However, the willingness of fiscal policymakers to relax the Stability and Growth Pact strongly hints at fiscal fatigue. Despite some consolidation, three countries (Belgium, Greece and Italy) still have gross general government debt ratios in excess of $80 \%$ of GDP. More importantly, officials have expressed concern about the threat of fiscal unsustainability in some countries as the euro-area population ages. ${ }^{55}$

At this stage, there remains little reason to predict an acute challenge. But, it is not difficult to imagine circumstances in which difficulties might arise. For example, the threat of a debt deflation could place an excessive burden on monetary policy to secure price stability without coordinated fiscal support. Achieving coordination among 15 or more fiscal decision makers (or even among a handful of large-country decision makers) makes the ECB's potential challenge more complex than that of other major central banks. ${ }^{56}$

We view the likelihood of a sustained, open conflict between monetary and aggregate fiscal policy as remote. As Sargent and Wallace (1981) famously showed a quarter century ago, such a conflict can undermine the inflation credibility even of a resolute central bank. Fortunately, there is little reason to anticipate such a clash. For example, recent Eurobarometer polls suggest that when inflation rises, popular awareness helps underpin the ECB's objective of price stability. ${ }^{57}$ And, despite evidence of fiscal fatigue over the past decade, peer pressure among fiscal

\footnotetext{
${ }^{54}$ Ignazio Angeloni: "If [cyclical and inflation] divergence persists, it could present problems. I regard these potentially as political risks, political strains.”

${ }^{55}$ Of current EMU members, a recent European Commission report (2007) that addresses fiscal sustainability and aging populations cited Greece and Portugal as "high-risk" cases. Only Austria, Finland and the Netherlands were "low risk."

56 Timothy Geithner: "They never resolved fundamentally what was going to be the framework of discipline on the fiscal side."
} 
policymakers has helped to limit the kind of post-EMU fiscal slippage that many skeptics anticipated.

Against the background of diverging competitiveness, a somewhat more likely (if still highly improbable) scenario would be a rise of market disturbances caused by the loss of confidence in a (group of) fiscal agent(s). Would such a fiscal crisis also threaten the stability of the regional financial system (say, by weakening institutional balance sheets and the credibility of national deposit insurance schemes)? The notable decline of home-country bias in euro-area debt after EMU almost surely has reduced "concentration risk" in the financial system (see Issing (22 May 2006)). Nevertheless, no central bank can afford to ignore the potential linkages between fiscal and financial instability. Consequently, it would be surprising if the ECB became less inclined to advocate fiscal prudence as it seeks to secure price stability.

\section{Exchange Rate Considerations}

The euro depreciated considerably in the early years of EMU. However, the ECB has never faced an exchange rate crisis similar to the one in the United States in the late 1970s: (1) a plunging currency; (2) rising inflation expectations; and (3) sharply weakening long-term financial markets. This may reflect another dividend of the ECB's anti-inflationary credibility. However, over the next decade, it is easy to imagine the combination of a continued unwinding of the large current account imbalances that have characterized the global economy over the past decade and an upward revaluation of currencies in some large emerging economies.

Discontinuities in this process could test the ECB's ability to work cooperatively with other central banks to limit disturbances in other financial markets and (thereby) to secure economic and price stability.

The key issues for the euro area will be to clarify who decides currency policy and what circumstances, if any, merit currency intervention. The ECB's track record now provides considerable confidence that these issues will be addressed successfully in the future. But the

\footnotetext{
${ }^{57}$ Asked to name the two most important issues facing their country, the share of persons in the euro area identifying rising prices or inflation jumped to $26 \%$ in the autumn of 2007 (making it the second item on the list), up from 16\% a year earlier (and a 16\% average of the previous three years).
} 
Maastricht Treaty’s allocation of authority for setting the currency regime to finance ministers leaves lingering uncertainties.

\section{Other Matters}

We close by mentioning without elaboration three additional challenges that surfaced in our interviews. First, some interviewees pointed to the loss of political will toward European integration as a potential source of added complexity in matters ranging from enlargement to financial stabilization. Second, there was concern that the generational turnover of leadership at the ECB in coming years will focus attention not only on the competence and diversity of new Executive Board members (and senior staff), but also on the potential for rigidities with respect to country representation. While the Treaty's mandate for ECB autonomy is very powerful, turnover also creates a risk that politicians least supportive of the ECB would promote candidates less zealously independent. Third, there was the hope that the pace of progress toward operational efficiency will reveal the ECB's ability to overcome national resistance to productivity-enhancing consolidation (e.g. in reducing the large number of physical mints).

\section{Conclusions}

John Taylor: "The biggest success has been to set it up from scratch, to deal with the inherent difficulties of communication and different traditions, and to have a policy apparatus which is basically working well in terms of interest rate decisions, et cetera. That has to be viewed as a major achievement. It's the first time anything like that has been done."

Philipp Hildebrand: "I sometimes have the impression that the ECB has more credibility than it gives itself credit for."

In reflecting on the first decade of European Monetary Union we are reminded of the story of the Vasa, the Swedish warship to which a museum is devoted in Stockholm. ${ }^{58}$ In an effort to build a symbol of Sweden's burgeoning naval power, King Gustavus II Adolphus ordered the construction of a large and elaborate ship. No expense was spared. To accommodate the 72 cannons cast for it, the Vasa was built with two gun decks rather than the usual one. The result

\footnotetext{
${ }^{58}$ For details of the Vasa's history and the museum, see http://www.vasamuseet.se/InEnglish/about.aspx.
} 
was a massive, top-heavy and unstable ship that the King nevertheless ordered to set sail on 10 August 1628. The Vasa sank almost immediately after encountering its first stiff breeze less than two kilometers from port.

There are two morals to the story of the Vasa. First, governments occasionally arrange large, prestigious projects that fail infamously. And second, experts do not like to convey bad news to kings or ministers about their pet projects. In the ECB's case, the Maastricht Treaty ventured where no vessel had gone before, but it has worked well. That success presumably owes to the design and the crew, not to the lack of turbulence.

Our ECB interviewees rightly express pride and satisfaction in their accomplishment. Literally thousands of people worked diligently for years to make monetary union not only a reality, but a success. It is difficult to find major fault with the operational framework or the monetary policy decisions of the first decade of EMU.

Indeed, with the broader perspective of time, many of the criticisms that have been addressed at the ECB appear ancillary in light of the euro area's track record of low and stable inflation and reasonably stable economic growth. The ECB focused effectively on price stability, while maintaining its Treaty-mandated independence. Critics acknowledge that the two-pillar strategy did not prompt the ECB to become overly restrictive for any sustained period, despite persistent overshoots of the monetary reference value. And, it is doubtful that ECB goal asymmetry is prompting a sustained rise of long-term inflation expectations, as some observers anticipated.

Naturally, policy strategy, implementation and communication should be routinely reviewed, and there is always room for improvement. Some outside observers have suggested that the ECB missed a key opportunity in 2003 to make greater progress toward best practice. Our own view is that the ECB leadership has demonstrated an open attitude to proposals for reform - including recommendations in the areas of strategy and communications - provided that the proposals adequately reflect the complex political constraints under which the ECB operates. 
Ultimately, with successes come new challenges. For the Eurosystem, our interviewees highlighted two: enlargement and financial stability. On the first, we see the constant addition of new countries as a tremendous challenge for both communication and policy setting itself. As the euro area expands, the addition of new constituencies that speak different languages, have different customs and histories, will complicate communication further. In addition, the more countries there are, the more likely that real divergence at the national level will arise. And, dramatically different productivity and labor market performance would place substantial stress on monetary union.

Once everything is said and done, the issue of financial stability seems paramount to us. The key problem is one of information and coordination during a crisis, as well as harmonization of procedures. It is extremely unlikely that Europe will create a supranational supervisory authority to complement the ECB in the foreseeable future. Nevertheless, we agree with the majority view expressed by our interviewees that in the absence of such a new organizational structure, the current one will need to work $a$ s if it were a single entity.

Returning to the accomplishments of the first decade of monetary union, our interviewees were unanimous in their conclusion that the ECB has many more successes than disappointments to its credit. We agree. 


\section{Appendix A: Questionnaire}

The following questionnaire was drafted in June 2007 and formed the basis for all of our interviews. In every case, we sent the questionnaire with our initial letter requesting an interview. We clearly stated in that letter that we would be happy to omit any question that the interviewee did not wish to answer. In one case, we discussed the questions with the interviewee in advance and agreed on some changes, which are noted below.

\section{Policy in the First Decade of Monetary Union}

a. Thinking back to 1998, what did you anticipate would be the biggest policy challenges? Now, nearly a decade later, what do you think the biggest policy challenges were? How did your policy goals evolve over time?

b. What were the ECB's most important policy successes and disappointments?

c. How has the decision-making process of the Governing Council evolved? How do the decision processes under the Duisenberg and Trichet presidencies compare? Has the process been smoother or more complicated than initially expected? ${ }^{*}$

d. On occasion, the relationship between the ECB and the political leaders of selected euro-area countries has been strained. How have these developments affected ECB policy determination?

\section{Policy in the Second Decade of Monetary Union}

a. Looking forward, what is the biggest challenge facing the euro area over the next decade?

b. Are the ECB's challenges different from those facing a "mature" central bank?

c. Communication policy is a work in progress for many central banks. Which of the world's central banks do you believe is at the frontier of best practice in communication policy? What aspects of that central bank's policy would you single out as worthy of emulation elsewhere? How do you see the ECB's communication policy evolving over the next few years?

d. Some observers express concern about the difficulties facing the ECB in personnel matters. How does the role of nationality in personnel selection affect confidence in the ECB and its governance? ${ }^{+}$

\section{Financial Stability}

a. Does the euro area face any unusual challenges in promoting financial stability?

b. Does the lack of direct responsibility for regulatory and supervisory matters create any obstacles for the ECB in pursuing its financial stability objective?

c. What is the biggest challenge for policy coordination in a crisis? What legal, regulatory or behavioral obstacles remain for effective coordination?

* For some of the interviewees we substituted the following question:

"How has the decision-making process of the Governing Council evolved over time?"

+ This question was omitted for some interviewees. 


\section{Appendix B: Common Themes}

Following is a summary of the themes that emerged from our interviews. For each question, we looked for similarities in the responses of the interviewees. Beyond that, we have used our judgment in creating the list. The results below should not be interpreted as implying agreement or consensus among the interviewees.

\section{Policy in the First Decade of Monetary Union a. Thinking back to 1998, what were the challenges?}

Strategy, Instruments, Communications were all open issues Unprecedented experiment with little time to prepare No track record (untested operational framework)

Absence of data at the outset

Uncertain transmission mechanism

Challenge of anchoring inflation expectations and creating credibility

Potential conflict between the ECB and the NCBs

Worries about fiscal policy and the Stability and Growth Pact

Concern that entry of many countries would destabilize EMU

Skepticism of external observers that the project would succeed

Challenge of creating a virtual currency initially

Euro area was not an optimal currency area - one size does not fit all

Structural inflexibility in the euro area economies

Difficulties created by enlargement

Hindsight: Goals were stable; optimal currency area fears were overdone; communication challenge underestimated

\section{b. Important successes \& disappointments}

\section{$\underline{\text { Successes }}$}

Rapid establishment of credibility and stable goals (mandate + legacy)

Overcame external shocks (not just luck)

Major advances in data collection and forecasting

Transparent policy strategy, especially the quantitative definition of price stability

Excellent track record: low inflation, stable inflation expectations, and low inflation volatility

Cooperation between the ECB and the NCBs

No major errors in interest-rate setting

An effective decision-making apparatus

Operational success in liquidity provision in crisis and foreign exchange intervention

Successfully guarded institutional independence from start

Effective international cooperation

Rapid money market integration; deep bond market integration

Euro has become a leading world currency

Consolidation of European banking and financial integration

2003 reform: altered communication strategy and use of policy framework

The euro yield curve was the best legacy yield curve at start

Avoided deflation panic

Effective personnel selection 


\section{Disappointments}

No internal disappointments

Lack of fiscal and structural reforms (thereby sustaining low potential growth)

Teething problems in communication strategy

Introduction of coins and notes leads to substantial perceived inflation

Pace of financial integration was not what had been hoped

Little impact on political unification that some proponents hoped would come

Lack of understanding of ECB's role vis-à-vis national governments, the NCBs, and the European Commission

Inflation sometimes above $2 \%$

Lack of a framework for financial stability

Some signs of divergence

\section{c. Has the decision-making process evolved?}

No major changes in decision-making process

Effective decision-making apparatus, including the role of the staff

Proposal power of Chief Economist at the start

No national arguments on monetary policy

Early consensus on the policy strategy

Eclectic, careful vetting of policy

Consensus does not mean unanimity

Evidence of rapid decisions in crises

EMI prep aided consensus

Evolution of the communication style

Less effective cooperation on banking and national economic policy

Infrastructure decisions more problematic

\section{d. Have politicians had an impact?}

Little or no impact of pressure on decisions

Successfully established and maintained institutional independence

Easy to resist pressure from one country

Treaty protects ECB well

Political debate reflects traditional differences

Political influences can cause volatility and confusion

Pressures arise from lack of popular support for ECB

ECB as a cheap target 


\title{
II. Policy in the Second Decade of Monetary Union
}

\author{
a. What are biggest challenges looking forward? \\ Maintaining popular support \\ Multi-national communications \\ Enlargement (the agreed upon voting system will help) \\ Maintain price stability in a credible regime \\ Financial stability \\ Real divergence \\ Fiscal and structural issues \\ Loss of political will (slow financial integration) \\ EU growth trend (competitiveness and dynamics)
}

\section{b. Is ECB mature?}

Most problems similar to those of other central banks

Enlargement

Multi-Country

Selection of next President and Vice President key

Transmission Mechanism still uncertain

Financial Stability

Federal System/Multiple Fiscal Agents

Issues outside conventional monetary policy

\section{c. Is there best practice in communication?}

No "one size fits all"

Communication policy is by its nature evolutionary

ECB transparency and accountability are high; there is no need for major change

Communication is necessarily shaped by history, language, diverse constituency

More talk does not mean more transparency

Two pillars aided at start, but for how long?

Successes: quantitative definition of price stability

Press conference as substitute for minutes

Not publishing votes promotes "euro-area" thinking

Would an inflation target be clearer?

Enlargement adds to communication challenge

Naïve to cite small-country central bank strategy as a model for ECB

\section{d. Nationality of the Board?}

Nationality irrelevant for staffing

High standard of personnel achieved

Favorable comparison to other international organizations

Nationality of Executive Board members is key; need wider rotation

What happens if UK enters? 


\section{III.Financial Stability}

\section{a. Unusual challenges in financial stability?}

Greatest contribution to financial stability is continued price stability

Liquidity provision is a joint ECB/NCB responsibility

Ex ante crisis management creates moral hazard

Bailouts have to be done by national governments with public funds

Financial regulatory process is in flux with overlapping jurisdictions in Europe, EU, Euro Area

Relationship among markets in different countries in flux

Various committees and MoUs promote cooperation, but the mechanism is complex

Eurosystem Marginal Lending Facility follows the Bagehot procedures

Common collateral framework makes the Lender of Last Resort operate more efficiently

There remains the danger of perpetuating insolvency through central bank lending

The key to crisis management is timely information exchange

Supervision needs to evolve with financial integration

Burden-sharing challenge rises with financial integration

Contrast: NCB Governor role in monetary policy versus role in financial stability

Pragmatic approach: European Secretariat

Early intervention needed (better incentives for market plus reduction of home/host stresses)

Real test will come with a solvency crisis in a recession

Decentralization creates a challenge in distinguishing illiquidity from insolvency

Lack of coordination could threaten competitiveness of European financial centers?

\section{b. Lack of regulatory and supervisory authority}

Supranational supervisor not necessary - complex coordination is a substitute

Doctrine: Close relationship between ECB and supervisory authorities

Exchange of information identified as key

Requires protocols to aid information flow under stress

NCBs provide relationship with counterparties

There may be an evolution toward more supranational approach?

National mandate, culture, practices, law hinder supervisors from working as one

Political resistance to European supervision

ECB can see unusual borrowing by an institution

Reforms needed not just for institutional design: Crisis handbooks, exercises

\section{c. Policy coordination in crisis?}

Multi-party coordination difficult

Burden sharing not centralized

Long evolution ahead

Greater diversity of circumstances and sophistication

Collateral regime insufficient with insolvency

Eurosystem lacks a clear New York Fed style liquidity desk

$\mathrm{CB}$ as natural leader in crisis (source of liquidity) 


\section{Appendix C: Brief Biographies of Interviewees}

We interviewed 17 high-level current and former officials, the majority of whom were directly involved in the creation of the monetary union. We sent out 22 interview requests. Two were declined; two agreed to interviews but we were unable to schedule them; and in one case we received no response.

Below we provide a very brief biographic sketch of each interviewee. In order to conserve space, we focus on the experience that is most relevant for our purposes. A complete biography of any of these people would run for pages. The date of the interview is in parentheses.

Dr. Ignazio Angeloni (13 September 2007): From September 1998 to December 2002, Dr. Angeloni was Deputy Director General in the Directorate Research at the European Central Bank. Prior to that he was at the Bank of Italy. At the time of the interview, Dr. Angeloni was Director for International Financial Relations at the Italian Treasury.

Dr. Jaime Caruana (1 November 2007): From 2000 to 2006, Dr. Caruana was Governor of the Bank of Spain, during which time he also served as Chairman of the Basel Committee on Banking Supervision (2003 to 2006). Prior to joining the Bank of Spain, Dr. Caruana held various positions in the Spanish Treasury. At the time of the interview, Dr. Caruana was Counsellor and Director of the Monetary and Capital Markets Department at the International Monetary Fund.

Sir Andrew Crockett (30 October 2007): From 1994 to 2003, Sir Andrew was the General Manager of the Bank for International Settlements. Prior to that, he held various positions at the Bank of England. At the time of the interview, Sir Andrew was President of JP Morgan Chase International.

Dr. Vitor Gaspar (29 August 2007): From September 1998 to December 2004, Dr. Gaspar was the Director-General Research at the European Central Bank. Prior to that he was Director of the Research and Statistics Department of Bank of Portugal and Director of Economic Studies at the Portuguese Ministry of Finance. At the time of the interview, Dr. Gaspar was Acting Director of the Bureau of European Policy Advisors at the European Commission.

President Timothy F. Geithner (16 November 2007): Since 2003, Mr. Geithner has been President of the Federal Reserve Bank of New York and Vice Chairman of the Federal Open Market Committee. He also serves as Chairman of the Committee of Payment and Settlement Systems. Prior to joining the Federal Reserve, Mr. Geithner held leading positions at the International Monetary Fund and the U.S. Treasury, where he was Under Secretary for International Affairs from 1999 to 2001.

Lord Edward George (9 January 2008): From 1993 to 2003, Lord George was Governor of the Bank of England, where he worked for his entire career beginning in 1962. At the time of the interview, he was a member of the House of Lords.

Dr. Sirkka Hämäläinen (9 October 2007): From 1998 to 2003, Dr. Hämäläinen was a member of the Executive Board of the European Central Bank. From 1992 to 1998, she was Governor of the Bank of Finland.

Vice Chairman Philipp M. Hildebrand (28 January 2008): Since 2003, Dr. Hildebrand has been a member of the Governing Board of the Swiss National Bank, and was named Vice Chairman in 2007. Prior to joining the Swiss National Bank, he held various positions in private financial institutions. 
Prof. Dr. Otmar Issing (29 June 2007): As a member of the Executive Board of the European Central Bank from June 1998 to May 2006 Professor Issing was responsible for the Directorates General Economics and Research. From 1990 to 1998 he was a member of the Board of the Deutsche Bundesbank with a seat in the Central Bank Council. From 1988 to 1990 he was a member of the Council of Economic Experts in Germany. At the time of the interview, Professor Issing was President of the Center for Financial Studies at the University of Frankfurt.

Baron Alexandre Lamfalussy (6 November 2007): From 1994 to 1997, Baron Lamfalussy was the founding President of the European Monetary Institute. Prior to that, he held various positions at the Bank for International Settlements, including serving as General Manager from 1985 to 1993. At the time of the interview, Baron Lamfalussy was Professor emeritus at the Catholic University of Louvain.

Governor Christian Noyer (27 February 2008): Since 2003, Mr. Noyer has been Governor of the Banque de France. From 1998 to 2002, he was the founding Vice President of the European Central Bank. Prior to joining the ECB, Mr. Noyer held leading positions at the French Treasury and Finance Ministry.

Vice President Lucas D. Papademos (15 November 2007): Since 2002, Dr. Papademos has been Vice President of the European Central Bank. Prior to taking his current position, beginning in 1994, he was Governor of the Bank of Greece.

Dr. Fabrizio Saccomanni (6 November 2007): Since 2006, Dr. Saccomanni has been Director General of the Bank of Italy. From 2003 to 2006, he was Vice President of the European Bank for Reconstruction and Development. Prior to that, Dr. Saccomanni held a variety of positions at the Bank of Italy.

Prof. John B. Taylor (25 January 2008): Professor Taylor is the Mary and Robert Raymond Professor of Economics at Stanford University and the Bowen H. and Janice Arthur McCoy Senior Fellow at the Hoover Institution. He has been a member of the faculty at Stanford University since 1984. During that period, Professor Taylor also has served as a member of the President's Council of Economic Advisers (1989 to 1991) and as Under Secretary of the Treasury for International Affairs (2001 to 2005).

Prof. Dr. Hans Tietmeyer (9 October 2007): From 1993 to 1999, Prof. Tietmeyer was President of the Deutsche Bundesbank. At the time of the interview, he was inter alia President of the European Business School, International University, Schloss Reichartshausen, Germany.

President Jean-Claude Trichet (14 December 2007): Since 2003, Mr. Trichet has been President of the European Central Bank. Prior to assuming his current position, he was Governor of the Banque de France starting in 1993, Undersecretary of the Treasury starting in 1987, and Counsellor of the President of the Republic until 1981.

President Axel A. Weber (10 October 2007): Professor Weber has been President of the Deutsche Bundesbank since April 2004. Prior to that he was Professor of International Economics at the University of Cologne and a member of the German Council of Economic Experts. 


\section{References}

Alesina, Alberto, Olivier Blanchard, Jordi, Galí, Francesco Giavazzi, and Harald Uhlig, Defining a Macroeconomic Framework for the Euro Area: Monitoring the European Central Bank 3, Centre for Economic Policy Research, 2001.

Andersson, Magnus, Lars Jul Hansen, and Szabolcs Sebestyén, "Which News Moves the Euro Area Bond Market?” ECB Working Paper Number 631, May 2006.

Bank of England, HM Treasury and Financial Services Authority, Financial stability and depositor protection: strengthening the framework, January 2008.

Begg, David, Fabio Canova, Paul De Grauwe, Antonio Fatás, and Philip R. Lane, Surviving the Slowdown: Monitoring the European Central Bank 4, Centre for Economic Policy Research, 2002.

Bini-Smaghi, Lorenzo, “The exchange rate policy of the Euro,” Speech at the Annual Meeting Association Française de Sciences Economiques La Sorbonne, 21 September 2007.

Cecchetti, Stephen G., Alfonso Flores-Lagunes, and Stefan Krause, "Has Monetary Policy Become More Efficient? A Cross-Country Analysis” Economic Journal, vol. 116, no. 4, April 2006, 408-433.

Cecchetti, Stephen G., Peter Hooper, Bruce Kasman, Kermit L. Schoenholtz and Mark W. Watson. Understanding the Evolving the Evolving Inflation Process. U.S. Monetary Policy Forum Report No. 1, Rosenberg Institute, Brandeis International Business School and Intiative on Global Financial Markets, University of Chicago Graduate School of Business, 2008.

Connolly, Bernard. The Rotten Heart of Europe: The Dirty War for Europe's Money. London: Faber and Faber, 1995.

Del Giovane, Paolo and Roberto Sabbatini, editors. The Euro, Inflation and Consumers' Perceptions: Lessons from Italy. Berlin: Springer-Verlag, 2008

Del Giovane, Paolo, Silvia Fabiani, and Roberto Sabbatini, "What's behind 'inflation perceptions'? A survey-based analysis of Italian consumers,” in Del Giovane, Paolo and Roberto Sabbatini, editors. The Euro, Inflation and Consumers’ Perceptions: Lessons from Italy. Berlin: Springer-Verlag, 2008

Dzuida, Wioletta and Giovanni Mastrobuoni, "The Euro Changeover and Its Effects on Price Transparency and Inflation,” unpublished manuscript, Kellogg School of Management, Northwestern University, July 2007.

Economic and Financial Committee, EFC 2007 Status Report on Information Requirements in EMU, October 2007.

Eijffinger, Sylvester C W, Geraats, Petra M, and Carin A B van der Cruijsen, "Does Central Bank Transparency Reduce Interest Rates?” Centre for Economic Policy Research Working Paper DP5526, March 2006.

Eijffinger, Sylvester C W and Carin A B van der Cruijsen, “Actual Versus Perceived Central Bank Transparency: The Case of the European Central Bank,” Tilburg University, October 2007.

Eurobarometer, various issues, European Commission. 
European Central Bank. The Monetary Policy of the ECB. $2^{\text {nd }}$ Edition, January 2004.

European Central Bank "Developments in the EU Framework for Financial Regulation, Supervision and Stability, ECB Monthly Bulletin, November 2004.

European Central Bank, “The Predictability of the ECB’s Monetary Policy,” ECB Monthly Bulletin, January 2006.

European Central Bank, The Implementation of Monetary Policy in the Euro Area: General Documentation on Eurosystem Monetary Policy Instruments and Procedures, September, 2006.

European Central Bank, “The EU arrangements for financial crisis management,” ECB Monthly Bulletin, February 2007.

European Central Bank, "Circulation and supply of euro banknotes and preparations for the second series of banknotes,” ECB Bulletin, October 2007.

European Central Bank, "Review of the Lamfalussy Framework: Eurosystem Contribution,” November, 2007: http://www.ecb.int/pub/pdf/other/lamfalussy-review2007en.pdf.

European Commission, European Economy, various issues.

European Commission, Public Finances in EMU, June 2007.

European Economic Advisory Group at CESifo, Report on the European Economy 2003, "Executive Summary.”

Eurostat, May 2003 Euro-zone annual inflation down to 1.9\%, Euro-Indicators News Release 69/2003, 18 June 2003.

Feldstein, Martin, “The Political Economy of the European Economic and Monetary Union: Political Sources of an Economic Liability,” Journal of Economic Perspectives, Vol. 11, no. 4 (Fall 1997): 23-42.

Fischer, Björn, Michele Lenza, Huw Pill, and Lucrezia Reichlin, Money and monetary policy: The ECB experience 1999-2006, November 6, 2006.

Galí, Jordi, Stefan Gerlach, Julio Rotemberg, Harald Uhlig, and Michael Woodford, The Monetary Policy Strategy of the ECB Reconsidered: Monitoring the European Central Bank 5, Centre for Economic Policy Research, 2004.

Garber, Peter M., “The TARGET Mechanism: Will It Propagate Or Stifle A Stage III Crisis?" CarnegieRochester Conference Series on Public Policy, volume 51, no 1 (December 1999), 195-220.

Gaspar, Vitor and Anil K Kashyap, "Stability First: Reflections Inspired by Otmar Issing's Success as the ECB's Chief Economist," prepared for the ECB Colloquium held in honor of Otmar Issing, revised April 2006.

Gaspar, Vitor, “Bagehot and Coase meet the Single European Market,” unpublished manuscript, European Commission, October 2006. 
Geraats, Petra, Francesco Giavazzi, and Charles Wyplosz, Transparency and Governance: Monitoring the European Central Bank 6, Centre for Economic Policy Research, 2008.

International Monetary Fund, World Economic Outlook, various issues.

Issing, Otmar, Vitor Gaspar, Ignazio Angeloni and Oreste Tristani. Monetary Policy in the Euro Area: Strategy and Decision-making at the European Central Bank. Cambridge, U.K.: Cambridge University Press, 2001.

Issing, Otmar, “Monetary and Financial Stability: Is there a Trade-off?” Speech presented at the Conference on "Monetary Stability, Financial Stability and the Business Cycle" 28-29 March 2003, Bank for International Settlements, Basle, Switzerland.

Issing, Otmar, "Financial Integration, Asset Prices, and Monetary Policy,” Speech presented at the Symposium on Capital Markets and Financial Integration in Europe, 10 May 2004.

Issing, Otmar, “Globalization, EMU and the Euro,” Speech presented at Vienna Conference on "Globalization: Opportunities and Challenges for the World, Europe and Austria," 22 May 2006.

Issing, Otmar, “The ECB's monetary policy strategy: Why did we chose a two pillar approach?” Paper presented at The role of money: money and monetary policy in the twenty-first century, European Central Bank, 10 November 2006.

Jansen, David-Jan and Jakob de Haan, "Statements of ECB Officials and Their Effect on the Level and Volatility of the Euro-Dollar Exchange Rate,” CESifo Working Paper No. 927, April 2003.

Jansen, David-Jan and Jakob de Haan, “Look Who’s Talking: ECB Communication During the First Years of EMU,” CESifo Working Paper No. 1263, August 2004.

Obstfeld, Maurice, “EMU: Ready or Not?” Princeton Essays in International Finance, no. 209, July 1998.

OECD Economic Outlook, various issues.

Papademos, Lucas, “The Role of Money: Money and Monetary Policy in the Twenty-First Century,” Speech at the Fourth ECB Central Banking Conference, Frankfurt am Main, 9 November 2006.

Papademos, Lucas, "Inflation and competitiveness divergences in the euro area countries: causes, consequences and policy responses,” Speech at Center for Financial Studies of the University of Frankfurt conference The ECB and its Watchers IX, Frankfurt am Main, 7 September 2007

Sargent, Thomas J. and Neil Wallace, “Some Unpleasant Monetarist Arithmetic,” Federal Reserve Bank of Minneapolis Quarterly Review, Fall 1981.

Stark, Juergen, “The Role of Money: Money and Monetary Policy in the Twenty-First Century,” Fourth ECB Central Banking Conference, 9 November 2006.

Svensson, Lars E.O. “The First Year of the Eurosystem: Inflation Targeting or Not?” American Economic Review, vol. 90, no.2, May 2000, pg. 95-99.

Tabellini, Guido, “Why did bank supervision fail?” VOX website, 19 March 2008. http://www.voxeu.com/index.php?q=node/994 
Weber, Axel, "How should central banks signal their intentions regarding future interest rates?"

Presented at Center for Financial Studies of the University of Frankfurt conference The ECB and its Watchers IX , 7 September 2007.

www.ifk-cfs.de/fileadmin/downloads/events/ecbwatchers/20070907ecb_weber.pdf 